\title{
Price-Fixing Agreements Under the Sherman Anti-Trust Law
}

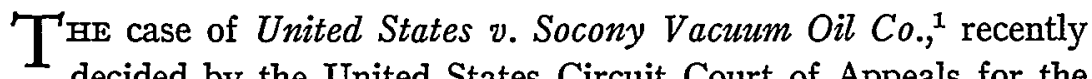
decided by the United States Circuit Court of Appeals for the Seventh Circuit, and now pending before the United States Supreme Court, indicates that the problem of the legality of price-fixing agreements under the antitrust laws is as far from solution as it ever was. In the Socony Vacuum case the trial judge submitted the case to the jury on the theory that the agreement there involved was an agreement embracing the raising of prices by a group controlling a substantial amount of the trade in a commodity and was therefore unlawful per se. ${ }^{2}$ The circuit court of appeals held this to be erroneous, either on the ground that the agreement involved was not a "pricefixing agreement" or that even if it were such it was not unlawful per se, the exact basis of the decision in this respect not being entirely clear. Whatever the basis of the decision may have been, the case clearly raises the question of the extent to which price-fixing agreements are proscribed by the Sherman Act. ${ }^{3}$ The increasing frequency with which the Federal Government, in its current drive for vigorous enforcement of the antitrust laws, ${ }^{4}$ is prosecuting or inves-

1 (C. C. A. 7th, 1939) 105 F. (2d) 809, rev'g United States v. Standard Oil Co. (W.D. Wis. 1938) 23 Fed. Supp. 937. Petitions for certiorari were granted by the United States Supreme Court on October 16, 1939. 60 Sup. Ct. 124, 84 L. ed. Adv. Ops. 90. The case was argued on February 5 and 6,1940 , the Court recognizing its importance by allowing four hours for oral argument. See 8 U. S. LAW WEEK 242, 247. See (1939) 39 Cor. L. Rev. 1441 ; (1940) 34 IrL. L. Rev. 619.

2 It is not entirely clear but seems probable that the effect of this instruction was modified by a later instruction which clearly made the validity of the agreenent turn on the presence or absence of control of the market. Thus the court paraphrased another instruction that if the defendants had the power, and combined for the purpose of raising the level of spot market prices, then "tlie restraint of trade was as a natter of law undue and unreasonable and, therefore, illegal." $105 \mathrm{~F}$. (2d) at 832.

326 STAT. (1890) 209, 15 U. S. C. (1934) §§ 1-7.

4 The current drive commenced in April, 1938. See Message of President Roosevelt to Congress, April 29, 1938, Sen. Doc. No. 173, 75th Cong. 3d Sess. On May 18, 1939, the Department of Justice stated its aim "to continue the existing policy of vigorous enforcenent." C. C. H. Trade Reg. Serv. (8th ed.) II 17022. This service will be cited hereinafter as C. C. H. See also Arnold, Prosecution Policy Under the Sherman Act (1938) 24 A. B. A. J. 417; Arnold, Fair and Effective Use of Present Antitrust Procedure (1938) 47 YaLe L. J. 1294. On Septenzber 29, 1939, the Antitrust Division of the Departinent stated that it "interprets the war as a new challenge which intensifies the need for its activity." C. C. H. I 15049. To like effect, see Arnold, Antitrust Activities of the Department of Justice (1939) 19 ORE. L. REv. 22. 
tigating claimed price-fixing agreements among competitors ${ }^{5}$ makes that question one of particular importance at this time.

5 Indictments recently retumed charging price-fixing are as follows: (1) United States v. Borden Co. (D. Il. Nov. 1, 1938) C. C. H. ॥ 17012 (charging fixing of prices of milk in Chicago area; demurrer sustamed on ground milk industry no longer subject to Sherman Act); United States v. Borden Co. (N. D. Ill. July 13, 1939) 28 Fed. Supp. 177, rev'd on latter point, Umited States v. Borden Co. (Dec. 4, 1939) 60 Sup. Ct. 182, 84 L. ed. Adv. Ops. 143; (2) United States v. Crown Zellerbach Corp. (N.D. Cal. July 12, 1939) C. C. H. I 15044 (charging agreement to fix prices of newsprint paper) ; (3) United States v. Underwood Elliott Fisher Co. (S. D. N. Y. July 28, 1939) C. C. H. II 15045 (charging agreement to maintain uniforın prices for typewriters); (4) United States v. Kraft Paper Ass'n (S.D.N.Y.Aug. 15, 1939) C.C.H. $\| 15047$ (charging agreement to limit production and maintain price of Kraft paper); (5) United States v. National Container Ass'n (S. D. N. Y. Aug. 15, 1939) C. C. H. If 15047 (charging allotment of production and artificial maintenance of non-competitive prices for shipping containers); (6) United States v. Hess (Nov. 3, 1939) C. C. H. If 15054 (charging fixing bids for electrical work on public works); (7) United States v. General Pet. Corp. (S. D. Cal.Nov. 14, 1939) C. C. H. I 15059 (charging conspiracy for artificially raising and maintaining prices of gasoline on Pacific Coast); (8) Umited States v. Long Island Sand \& Gravel Producers Ass'n (S. D. N. Y. Nov. 22, 1939) C. C. H. If 15060 (charging fixing of prices of sand and gravel) ; (9) United States v. The Simes Co. (S.D.N. Y. Dec. 15, 1939) C. C. H. If 15062 (charging fixing prices of electrical lighting fixtures in New York); (10) Indictment of members of cut stone and plywood industry (Feb.1,1940) Oakland Tribune, Feb. 1, 1940 , at 10.

Indictments and investigations charging price-fixing seem to outnumber all other types of violation charged since the present drive was inaugurated. The President indicated in his Message of April 29, 1938, op. cit. supra note 4, at 4, that price-fixing agreements were one of the main reasons for the drive. Thus lie said: "One of the primary causes for our present difficulties lies in the disappearance of price competition in many industrial fields. ... When prices are privately managed at levels above those which would be determined by free competition, everybody pays. . . . Even the Government itself is unable, in a large range of materials, to obtain competitive bids. It is repeatedly confronted with bids identical to the last cent." Ibid. See also Arnold, op. cit. supra note 4, at 1295; Jackson, Should the Antitrust Laves be Revised? (1937) 71 U.S. L. REv. 575, 578.

Pending investigations by the Department of Justice looking toward indictments charging price-fixing are: (1) Detroit Milk Investigation (Oct. 15, 1938) C. C. H. \17009; (2) Investigation of Fertilizer Industry (March 1, 1939) C. C. H. II 17015; (3) Middle West Oil Investigation (May 17, 1939) C. C. H. I 17021; (4) Wood Stick Investigation (May 23, 1939) C. C. H. \ 17024; (5) Investigation of Control of Trade Ass'ns by Management Engineering Cos. (June 27, 1939) C. C. H. $\|$ 17026; (6) Investigation of Building Industry (Oct. 3, 1939) C. C. H. I 17032.

The following Federal Trade Commission complaints charging price-fixing agreements contrary to section 5 of the Federal Trade Commission Act [38 STAT. (1914) 717, 719,15 U.S. C. (1934) $\S 45$ ] have been issued subsequent to April, 1938, against the following respondents: (1) Food Dish Associates of America (May 3, 1938) C. C. H. II 9503, cease and desist order issued (Dec. 9, 1938) C. C. H. If 9834; (2) The Hardwood Institute (May 12, 1938) C. C. H. If 9516; (3) Calciun Chloride Ass'n (Dec. 13, 1938) C. C. H. I 9855 ; (4) Rowe Mfg. Co. (Aug. 17, 1938) C. C. H. $\| 9705$ (corn cribs and silos) ; (5) United States Maltster's Ass'n (Aug. 24, 1938) C. C. H. If 9706; (6) Pine Hill Lime \& Stone Co. (Sept. 16, 1938) C. C. H. III 9736, 9970.74 (lime); (7) Lead Pencil 
The United States Supreme Court, after struggling for many years with the question of the proper construction of the Sherman Act, apparently settled that question in the Standard Oil case ${ }^{6}$ in 1911 when it announced the famous "rule of reason." By the Court's own statement that rule was to be applied "in every case where it is claimed that an act or acts are in violation of the statute..." ${ }^{7}$ But in the later case of United States $v$. Trenton Potteries $\mathrm{Co}^{8}$ the Court announced that a "price-fixing agreenent" was in itself an unreasonable restraint so that no other or further allegation or proof of unreasonableness was necessary. This circumlocution virtually created an exception to the rule of reason. As far as this writer is aware, no other such exception has thus far been created by the Court, and the rule stands that the validity of all agreements or combinations under the Sherman Act are to be determined by the reasonableness of the restraint effected thereby unless the agreement constitutes a "pricefixing agreement" within the meaning of the Trenton Potteries case, in which event the agreement is itself an unreasonable restraint and unlawful per se. The scope and extent of this exception to the rule of reason is extremely blurred at the present time, however, for four reasons: (1) uncertainty as to what constitutes a "price-fixing agreement" within the meaning of the Trenton Potteries case; (2) uncertainty as to the primciple announced in that case; (3) uncertainty as to whether that case has not been overruled or substantially modified by later cases and the exception eliminated; and (4) doubt as to the correctness of the principles therein decided, raising the question whether the exception should not now be eliminated if that has not been done already.

That great doubt exists as to what constitutes a "price-fixing

Ass'n (Nov. 1, 1938) C. C. H. II 9812 (lead pencils), cease and desist order issued (Aug. 28, 1939) C. C. H. $\llbracket 9971.12$; (8) Hardwood Charcoal Co. (Dec. 20, 1938) C. C. H. II 9863 ; (9) Mueller Co. (Jan. 24, 1939) C. C. H. II 9913 (pipe fittings), cease and desist order issued (April 5, 1939) C. C. H. \9959.96; (10) Book Paper Mfrs. Ass'n (April 13, 1939) C. C. H. II 9960.12; (11) National Converters Institute (Sept. 19, 1939) C. C. H. II 9971.49 (cellulose sheeting products); (12) Bluefield Coal \& Coke Co. (Oct. 5, 1939) C. C. H. II 9971.80 (wholesale coal dealers) ; (13) Milwaukee Jewish Kosher Delicatessen Ass'n (Oct. 4, 1939) C. C. H. If 9971.77 ; (14) Michigan Bean Shippers Ass'n (Oct. 27, 1939) C. C. H. If 9972.19 ; (15) National Capital Ice Institute (Nov. 10, 1939) C. C. H. If 9972.39 ; (16) Compressed Air Institute (Nov. 24, 1939) C. C. H. II 9972.59 (compressed air machinery); (17) Reading Batteries Inc. (Dec. 20, 1939) C. C. H. If 9973.11 (storage batteries).

6 Standard Oil Co. v. Umited States (1911) 221 U. S. 1.

7 Ibid. at 66 .

8 (1927) 273 U.S. 392. 
agreement" within the meaning of the Trenton Potteries case is plain. The case itself involved an agreement on specific uniform selling prices by.competing sellers. This is the clearest example of a pricefixing agreement and the one which most readily occurs when the term "price-fixing agreement" is used. But in the course of its opinion the Court also treated the following as if they too were to be regarded as price-fixing agreements: (1) agreements by competing sellers fixing minimum selling prices; ${ }^{9}$ (2) agreements by competing buyers setting up an agency with power to fix uniform purchase prices for all; $;^{10}$ (3) agreements by competing sellers establishing a committee, board, or other agency, and conferring on such agency the power to fix prices for all ${ }^{11}$ (4) vertical agreements by sellers with their buyers providing for the maintenance of resale prices of goods sold. ${ }^{12}$ From the illustrations thus given by the Court it might well be concluded that the only type of agreement included within the term "price-fixing agreement" as used in this case is an agreenient by which specific, niaximum, or ninimum selling or purchase prices are directly fixed, or an agency set up with authority directly to fix such prices. It is clear, however, that many other types of agreement necessarily restrain trade more than one directly fixing prices. Agreenients of this type include those providing for (1) the establishing of a trust for the joint management of competing enterprises $;^{13}(2)$ the pooling of profits; ${ }^{14}(3)$ the division of territory or

${ }^{3}$ In the course of the opinion the Court approved as a parallel case the decision in People v. Sheldon (1893) 139 N. Y. 251, 34 N. E. 785, involving an agreement fixing minimum selling prices. 273 U.S. at 400, n. 1 .

${ }^{10}$ The Court approved and regarded as parallel the cases of Live Poultry Dealers Protective Ass'n v. United States (C. C. A. 2d, 1924) 4 F. (2d) 840 (273 U. S. at 401), and People v. Milk Exchange (1895) 145 N. Y. 267, 39 N. E. 1062 (273 U. S. 400, n. 1). 11 The Court treated as a parallel case that of United States v. Trans-Missouri Freight Ass'n (1897) 166 U. S. 290, rev'g (C. C. A. 8th, 1893) 58 Fed. 58, which condemned an agreement vesting a committee of an association of railroads with power to fix railroad rates. 273 U. S. at 398. See Anheuser-Busch Brewing Ass'n v. Houck (Tex. Civ. App. 1894) 27 S. W. 692, 696: "The agreement did not in terms fix the price of beer, but it provided for it independently of the individual discretion of the several parties, which, it seems to us, is in effect the saine."

12 The Court regarded Dr. Miles Medical Co. v. John D. Park \& Sons Co. (1911) 220 U. S. 373 , condemning such an agreement, as a parallel case. 273 U. S. at $399,401$. 13 See the voting trust arrangement condemned in People v. North River Sugar Refining Co. (1890) 121 N. Y. 582, 24 N. E. 834. See also the joint management arrangement condemned in Hilton v. Eckersley (1855) 6 E. \& B. 47.

14 See Anderson v. Jett (1889) $89 \mathrm{Ky} .375,12 \mathrm{~S}$. W. 670, condemning agreement between rival steamboat operators for pooling of profits and recognizing the point here made. It was there said: "It is true that their contract did not, in so many words, bind them to any given charges; but it made it to the interest of each, not only to charge, but 
markets ${ }^{15}$ and (4) the termination of all competition between the parties, not ancillary to the sale of a business or the good will thereof. ${ }^{16}$ The latter types of agreement, while resulting in the elimination of price competition between the parties thereto, also result in the elimination of all other competition as well, and accordingly there is much greater reason for regarding them as uulawful than there is for regarding an agreement which, by directly fixing prices, eliminates only price competition, as unlawful. Accordingly, the decision in the Trenton Potteries case seems to carry with it a condemnation of this type of agreement to the same extent as it condemns agreements directly fixing prices. It would seem proper, therefore, to regard agreements which result in the elimination of price competition as "price-fixing agreements" within the rule of that case.

The agreement in the Socony Vacuum case was of quite a different character, however. The case involved an agreement by several gasoline producers having outstanding contracts with jobbers who had agreed to purchase of them, over long periods of time, large quantities of gasoline (virtually all their requirements for such periods), and to pay therefor the price prevailing on the spot market on the date of delivery. By the challenged agreement of the producers large purchases of gasoline were to be made by thein on the spot market for the professed purpose of stabilizing the spot price but obviously affecting in a very substantial way the price applicable under the jobbers' contracts. Thus prices were not directly fixed, nor was price competition between the parties thereto eliminated. Quite clearly, however, prices were very directly affected by the agreement, In this respect it was similar to an agreement limiting production. Whether this type of agreement, which, while directly affecting prices, does not contemplate or result in the direct fixing of prices or the elimination of price competition between the parties thereto, also is to be deemed a price-fixing agreement within the

to encourage and sustain the other in charges that would amount to confiscation." Ibid. at 379, $12 \mathrm{~S}$. W. at 671. See also United States v. Trans-Missouri Freight Ass'n (C. C. A. 8 tb, 1893) $58 \mathrm{Fed} .58,65$, where this precise distinction between an agreement pooling profits and one directly fixing prices is pointed out and applied, the court indicating that the former were unlawful per se at common law, while the latter were unlawful only if unreasonable.

15 Wickens v. Evans (1829) 3 Y. \& J. 318; Collins v. Locke (1879) 4 App. Cas. 674.

16 Leslie v. Lorillard Co. (1888) 110 N. Y. 519, 18 N. E. 363 ; Kellogg v. Larkin (Wis. 1851) 3 Pin. 123, (1886) 56 Ain. Dec. 164. Leshe v. Lorillard Co. involved an agreement between rival steamship companies whereby, for a money consideration, one company agreed no longer to run its steamships over a certain route. 
Trenton Potteries exception was one of the main questions involved in the Socony Vacuum case. It is obvious that if the exception is deemed to cover all agreements "affecting" prices as well as those "fixing" prices, then we will have returned substantially closer to the rule of the Trans-Missouri case $^{17}$ that all restraints are unlawful regardless of the reasonableness thereof, for it would seem clear that most, if not all, agreements among competitors "affect" prices in some way, either directly or indirectly. The other main question involved in the Socony Vacuum case, and the one also presented by the various criminal prosecutions ${ }^{18}$ and other proceedings charging agreements fixing prices mentioned above, ${ }^{10}$ is the present status and scope of that exception-moreover whether the exception any longer exists and if it does whether it should not now be repudiated.

The scope of the rule declared in the Trenton Potteries case is extremely uncertain due to the ambiguous language used in the opinion of the Court in that case. That language makes it doubtful whether its rule extends to and condemns as in themselves unreasonable restraints: (1) all price-fixing agreements; ${ }^{20}$ (2) only those price-fix-

\section{Supra note 11.}

18 See supra note 5. The Department of Justice has taken the vicw that in the present drive criminal proceedings should be instituted rather than suits for injunctions. "Only in exceptional instances when the institution of criminal proceedings would be incquitable because of acquiescence in the practices complained of will the injunctive remedy be used as a substitute for a criminal proceeding." Statement of Grounds for Action in Investigation of Milk and Ice Cream Industries in Chicago. Dept. of Justice Release, July 7, 1938, in C. C. H. 117004 , p. 23307 . Arnold, op. cit. szcpra note 4, at 1299. As a result, criminal prosecutions are now the rule and injunction proceedimgs the exception. Prior to the present drive the reverse was true. See Tre Federal ANtitrust Laws, Witr Sumparary of Cases Instituted by the United Statrs (1938) 81-269. The publication last cited shows that from 1890 to January 1,1938 , the Government has instituted 428 proceedings under the antitrust laws, 232 of them heing suits in equity, and 196 being criminal prosecutions. Frown 1906 to 1911 criminal prosecutions seem to have been the rule, while from 1924 to 1938 suits in equity greatly preponderated over criminal prosecutions. Ibid. See Montague, The Defects of the Sherman Anti-Trust Law (1909) 19 YALE L. J 88, for account of enforceinent of Act prior to 1909. See HAdLICK, CRDunNar Prosecutions UNDER THE SHERMan ANTI-Trust ACT (1939) for extensive discussion of probleins arising in criminal proceedings. On February 20, 1939, the Government apparently for the first time in the history of the Act brought an action to recover treble damages for violation of the Sherman Act, caused by collusive bidding on government contracts. United States v. Cooper Corp. (S. D. N. Y. Feb. 20, 1939) C. C. H. II 17013. See also Note (1939) 49 YaIE L. J. 284.

10 See supra note 5.

20 Many passages of the opinion of Mr. Justice Stone support this construction of the decision. Thus at 273 U. S. 397, Mr. Justice Stone niakes remarks condemnatory of "every price-fixing agreement," and at page 400 he indicates that "any agreement for price-fixing, if found, would have heen illegal as a matter of law." In note 1, page 400, 
ing agreements entered into by parties "controlling a substantial part of an industry"; ${ }^{21}$ or (3) only those price-fixing agreements entered into by parties who control the market, ${ }^{22}$ i.e., who have power to dictate the market price according to their own discretion. Another possible interpretation of the decision is that it holds only that a price-

articles cited, taking the view that all price-fixing agreements are unlawful per se at common law and under the Sherman Act, are approved, i.e., Pope, The Legal Aspect of Monopoly (1907) 20 HaRv. I. REv. 167, 168; Watkins, The Change in Trust Policy (1922) 35 ibid. 815,821 . At 273 U. S. 398 he quotes with approval Taft's dicta in the Addyston Pipe case, infra note 27, supporting this view. These and other passages have led many writers to interpret the case as condemning all price-fixing agreements as unlawful per se. HADLICK, op. cit. supra note 18, at 160; Podell (successful counsel for government in Trenton Potteries case) in HANDLER, THE FEDERAI ANTI-TRUST LAws-A StMrostum (1932) 70; Royce in HandLER, ibid. at 224; KIRSH and SHAPIRo, Trade Assoctations IN LAw and Bustness (1938) 328; Burns, The Anti-trust Laws and the Regulation of Price Competition (1937) 4 LAw \& ConTexrp. Pros. 301, 304; Handler, The Sugar Institute Case and the Present Status of the Anti-Trust Lanes (1936) 36 Cox. L. REv. 1, 5; Jaffe and Tohriner, The Legality of Price-Fixing Agreements (1932) 45 HARv. L. REv. 1164, 1178; Levy, The Sherman Law is Outworm. It Should be Amended (1927) 13 VA. L. REv. 597, 606, 610; Naujoks, Monopoly and Restraint of Trade Under the Sherman Act (1929) 5 WIs. L. REv. 129, 137; Tobriner, Trade Depression and the Sherman Act (1931) 65 U. S. L. REv. 663, 665; Notes (1933) 13 B. U. L. REv. 501; (1933) 1 Geo. WasH. L. Rev. 507, 510; (1938) 51 Harv. L. Rev. 694, 698; (1940) 34 ILL. L. Rev. 619; (1932) 80 U. of PA. L. Rev. 730, 733; (1933) 19 VA. L. Rev. 851, 862; (1927) 7 B. U. L. REv. 322; (1936) 31 IlL. L. Rev. 118, 119; (1927) 11 MaRQUETTE L. REV. 163.

21 The instruction of the trial court which was upheld as correct was: "... the law is clear that an agreement on the part of the members of a combination controlling $a$ substantial part of an industry, upon the prices which the members are to charge for their commodity, is in itself an undue and unreasonable restraint of trade and commerce...." 273 U. S. at 396 . (Italics added.) The requirement that the members control "'a substantial part of an industry" may amount only to a requirement that their business be large enough to be of some consequence and does not seem to impose any requirement of monopoly power or control of the market. Some writers are at pains to insert these modifying words in their statement of the rule of the Trenton Potteries case. Tobriner and Jaffe, Revision of the Anti-Trust Laws (1932) 20 CaIIF. L. REv. 585.

22 This construction is supported by the Court's special mention of the fact that actually the combination controlled 82 per cent of the busimess of manufacturing and distributing in the Umited States of sanitary pottery. $273 \mathrm{U}$. S. at 394. The later reference to the trial court's instruction, supra note 21 , and the Court's remarks that the power to fix prices "involves power to control the market and to fix arbitrary and unreasonable prices" (273 U.S. at 397), is a strong indication that its decision was limited to agreements by parties who actually have the power to fix arbitrary and unreasonable prices. This construction of the case has been made by several writers. Donovan, The Need for Revision of the Anti-Trust Laws (1936) 22 A. B. A. J. 797, 800; Ryan, Industrial Recovery and tire Anti-Trust Lares (1933) 13 B. U. L. REv. 577, 590. It was actually adopted by the Supreme Court in Appalachian Coals, Inc. v. United States (1933) 288 U. S. 344, 375, where Chief Justice Hughes (who was the losing counsel in the Trenton Potteries case) said that in that case defendants had combined to fix prices and "It was found that they had the power to do this and had exerted it." 
fixing agreement may not be justified solely on the ground that the the prices fixed or resulting therefrom are in fact reasonable. ${ }^{23}$

Decisions subsequent to the Trenton Potteries case have not served to eliminate this uncertainty but to add thereto by introducing the possibility of the ultimate adoption, if that has not already occurred, of either of three other views: (1) that no price-fixing agreements are unlawful per se, even if the parties thereto control the inarket, but all such agreements are to be governed by the rule of reason and condemned only if otherwise found to be unreasonable restraints of trade; ${ }^{24}$ or (2) that price-fixing agreements, while unlawful per se where made by parties who control the market, are presumptively valid where such control is lacking and the burden is on the prosecution or the plaintiff to allege and prove them to be unreasonable restraints; ${ }^{25}$ or (3) that price-fixing agreements are unlawful per se where the parties thereto control the market, and are presumptively unlawful even where such control is lacking, but in the latter event may be shown by the defense to be reasonable. ${ }^{20}$

This present uncertainty would seem to warrant a review of the law on this subject with the object of determining the present status of price-fixing agreements under the Sherman Act. Because of the great vacillation shown by the Supreme Court on the question it would also seem proper to examine and review the subject from its beginmings. Only in this manner can it be determined whether the rule pronounced in the Trenton Potteries case is a sound one, or

23 Much of the opinion is devoted to discussion and establishment of the proposition that "it does not follow that agreements to fix or maintain prices are reasonable restraints and therefore permitted by statute, merely because the prices themselves are reasonable." 273 U. S. at 396 . The opinion is clearly susceptible of the construction that it merely prevents parties from justifying a price-fixing agreement under the Act on the sole ground that the prices fixed are reasonable, and does not necessarily prevent them from justifying such an agreecment on other grounds. Some writers seem to take this view of the case. Kirsh in HANDLER, op. cit. supra note 20, at 97; Montague in HaNDLER, ibid. at 40 .

24 As will heremafter appear in greater detail this view would find some, although not conclusive, support in Appalachian Coals, Inc. v. United States, supra note 22, at 359; Sugar Institute v. United States (1936) 297 U. S. 553, 597; and Interstate Circuit, Inc. v. United States (1939) 306 U. S. 208, 232.

25 Standard Oil Co. v. United States (1931) 283 U. S. 163, 175-179. See Handler, op. cit. supra note 20, at 22 ; Note (1932) 32 CoL. L. REV. 290, 308.

26 Appalachian Coals, Inc. v. Umited States, supra note 22, at 373. Mr. Burns takes the view that in this case the Supreme Court "retired" from the position taken in the Trenton Potteries case. Burns, op. cit. supra note 20, at 304. To like effect see Note (1933) 19 VA. L. Rev. 851. 
whether it rests upon premises which are untenable and should now be repudiated.

A necessary starting point for such a review is a consideration of the common law authorities on the question of whether price-fixing agreements were unlawful as being in restraint of trade. ${ }^{27}$ As is well known, the common law built up an extensive body of precedents on this question. These precedents have frequently been discussed in and have greatly influenced and formed the basis of decisions in Sherman Act cases. But this is not all. When the Supreme Court announced the "rule of reason" in the Standard Oil case ${ }^{28}$ it purported

27 Later English and American authorities have asserted that the only effect of illegality at common law was that the agreement would be deemed unenforceable by the parties thereto, that the agreeement was not illegal in the sense of being criminal, and that damages could not be recovered by third parties injured by the agreement. United States v. Addyston Pipe \& Steel Co. (C. C. A. 6th, 1898) 85 Fed. 271, 279, aff'd, (1899) 175 U. S. 211; Hansen Packing Co. v. Swift \& Co. (S. D. N. Y. 1939) 27 Fed. Supp. 364, 367 ; Mogul Steamship Co. v. McGregor [1892] A. C. 25, 39 ; Note (1934) 92 A. L. R. 185. The conclusion as far as price-fixing agreements are concerned fails to take into account authorities later discussed herein which show that prior to 1800 such agreements were treated as common law crimes and were so prosecuted and punished. It is in accord with statements made in later English cases, however. With respect to the question of damages the statement also finds abundant support in the cases. While the contention seems never to have been made, it would seem that the treble damage action given by the Statute of Monopolies, 21 JAC. I (1623) c. 3, § 4, to any person "grieved" by pretext of "any monopoly" might very plausibly have been invoked in support of the view that damages -even treble damages - were recoverable at common law. While the statute was addressed to monopohies created by royal grant, the subsequent expansion of the term "monopoly" described by Chief Justice White in Standard Oil Co. v. United States, supra note 6, at 52 et seq., might well support such an argunient. Mr. Walker contends that the Statute of Monopolies was not limited to monopolies by royal grant but extended to those created by private individuals as well. See Walker, Review of the Opinions of the Supreme Court of the United States in the Standard Oil and Tobacco Cases (1911) 73 CENT. L. J. 21, 22. See also Jaffe and Tobriner, op. cit. supra note 20, at 1166; Watkins, Anti-Trust Laws a Protection to Monopoly (1923) 96 CENT L. J. 188.

28 Supra note 6, at 51, 59, 60. See also Northern Securities Co. v. United States (1904) 193 U. S. 197, 339. And see Watkins, op. cit. supra note 20, at 816. "The statement is ventured that all of the prevailing decisions of the United States Supreme Court under that law would have been decided in the same way in which the Supreme Court has decided them, if the Sherman Law, so far as its substantive provisions are concerned, had merely provided in proper phraseology that the existing common law on the subject was declared to be the law of the United States and had provided appropriate penalties." Levy, The Federal Anti-Trust Law and the "Rule of Reason" (1913) 1 VA. L. REv. 188, 190. See also Hottenstem, The Sherman Anti-Trust Law (1910) 44 Am. L. REv. 827, 829; Kreider, Growth of Anti-Trust Legislation (1934) 7 So. CAxrF. L. Rev. 144, 147; Levy, The Sherman Law and the English Doctrine (1920) 6 CoRN. L. Q. 36, 38; Nagel, The Origin and Purpose of the Sherman Act (1930) 15 St. Lours L. Rev. 313, 318; Naujoks, Monopoty and Restraint of Trade Under the Sherman Act (1928) 4 WIs. L. REv. 385, 423; Noble, The Sherman Anti-Trust Act and Industrial Combinations (1910) 44 Asr. L. REv. 177, 197; Notes (1913) 13 Cor. L. REv. 421; (1914) 2 VA. L. REy. 140 ("Congress 
to adopt as a basis therefor the rules established by these common law precedents. And the view that the Sherman Act was designed only to declare a federal crime what had been previously held unlawful restraint of trade at common law has strong support in the Congressional debates which took place at the time of the enactment of the Sherman Act. ${ }^{29}$

Finally, in Connally v. General Construction $\mathrm{Co}^{30}$ and in Cline v. Frink Dairy Co., ${ }^{31}$ the Supreme Court raised these precedents to

intended the Sherman Act to be declaratory of the common law. . . ."). But see Adler, Monopolizing at Common Law and Under Section Two of the Sherman Act (1917) 31 HaRv. L. REv. 246, 251: "Congress was under the impression that by that section it was making illegal certain contracts, etc., which theretofore had not been considered illegal under the common law." See also Kales, The Sherman Act (1918) 31 HARv. L. Rev. 412,413 . In two instances state antitrust laws expressly provide that only contracts, combinations, or conspiracies which violate the common law are prohibited. Mass. Laws 1908, c. $454, \S 1$; N. C. Laws 1913, c. $41, \S \S 2,5$.

29 Senator Sherman said on March 21, 1890: "Mr. President, the object of this bill, as shown by the title, is 'to declare unlawful trusts and combinations in restraint of trade and production.' It declares that certain contracts are against public pohicy, null and void. It does not announce a new principle of law, but applies old and well recognized principles of the common law to the complicated jurisdiction of the State and Federal Government." (1890) 21 Cong. Rec. 2456. See Walker, History or the SHeraran Law (1910) 12,14 . See also other references to legislative history and debates collected in Handler, Cases on Trade Regulation (1937) 208. Cf. Homblower, "Anti-Trust" Legislation and Litigation (1911) 11 Cor. L. REv. 701, to the effect that the Sherman Antitrust Law is not attributable to Senator Sherman, but to Senator Hoar. This statement is based on the autobiography of Senator Hoar, who claimed to be the sole author of the law as finally enacted. 2 Hoar, AutobiograpHY of SEvenTy Yrars (1903) 363. Mr. Boudin regards it as settled beyond controversy that Senator Hoar wrote the Act. Boudin, The Sherman Act and Labor Disputes: I (1939) 39 Coz. L. Rev. 1283, 1290. Mr. Walker disputes this claim in (1911) 73 CENT L. J. 257, contending Senator Sherman was the real author. And Professor McLaughlin is of the same view, regarding Senator Hoar's statement that he is the author of the Act as "inaccurate and unjust." McLaugrnIn, Cases on tere Federat AntI-Trust Laws of tee United States (1933) 7. Whether Senator Sherman or Senator Hoar is the author of the Act is not material here in view of the fact that Senator Hoar also regarded the Act as declaratory of the common law. See Nagel, loc. cit. supra note 28; Washburn, The History of a Statute (1928) 8 B. U. L. REv. 95, 99. Professor Bennan had still another theory, that neither Senator Shennan nor Senator Hoar but Senator Edmunds wrote the Act. BERMAN, LABOR AND THE SHERMaAN Act (1930) c. 3. Mr. Boudim, supra, takes issue with this theory and holds in favor of Senator Hoar.

30 (1926) 269 U. S. 385, holding void for uncertainty an Oklahoma statute [OKrA. Conrp. STAT. (Bunn. 1921) § 7255] providing that "not less than the current rate of per diem wages in the locality where the work is performed" shall be paid to laborers, workmen, mechanics, or other persons employed by contractors or sub-contractors in the execution of any contract with the state.

31 (1927) 274 U. S. 445 , holding void for uncertainty the Colorado antitrust law (Colo. Laws 1913, c. 161) which forbade contracts and combinations in restraint of trade but contained a proviso that no agreement should be deemed unlawful "the object and 
even greater dignity and in fact seems in effect to have frozen them into the Act. In both these cases the Court was confronted with state statutes which were assailed as beimg so vague and uncertain in their terms as to constitute a denial of due process of law. ${ }^{32}$ In each case it was urged in support of the respective statutes that they were no more uncertain than the Sherman Act, whose only standard was that a contract, combination, or conspiracy should not "unreasonably" restrain trade within the rule of reason, and that the Sherman Act had been held not too uncertain to satisfy the requirements of due process of law in Nash $v$. United States. ${ }^{33}$ The reply of the Court in each case was the same: that the Sherman Act was not uncertam since the rule of reason embodied only the rules declared by these common law precedents and therefore afforded a definite and certain objective standard-one sufficient to satisfy the requirements of due process. Thus in Connally v. General Construction Co. ${ }^{34} \mathrm{Mr}$. Justice Sutherland said that the Sherman Act was not subject to the objection of uncertainty because its prohibitory language had "a wellsettled common law meaning, notwithstanding an element of degree in the definition as to which estimates might differ." And in the Cline case, ${ }^{35}$ Mr. Chief Justice Taft said:

"In the Nash case we held that the common law precedents as to what constituted an undue restraint of trade were quite specific enough to advise one engaged in interstate trade and commerce what he could and could not do under the statute."

Since the statutes involved in the Connally and Cline cases did not have the support of a body of common law precedents to give cer-

purposes of which are to conduct operations at a reasonable profit or to market at a reasonable profit those products which cannot be otherwise so marketed."

32 ". . . a statute which either forbids or requires the doing of an act in terms so vague that men of common intelligence must necessarily guess at its meaning and differ as to its application, violates the first essential of due process of law." Mr. Justice Sutherland in Connally v. General Construction Co., supra note 30, at 391. The principle of this and other cases declaring statutes void for uncertainty and a denial of due process is not confined to criminal eases but is equally applicable to civil. See A. B. Small Co. v. American Sugar Refining Co. (1925) 267 U. S. 233, 239. See Note (1931) 45 HaRv. L. REv. 160, entitled Indefinite Criteria of Definiteness in Statutes. A majority of the members of the present Supreme Court have recognized and applied this rule. Lanzetta v. New Jersey (1939) 306 U. S. 451, 453.

33 (1913) 229 U. S. 373. The Court did not actually say in this case that the Act was certain because embodying common law precedents.

34 Supra note 30 , at 391 .

35 Supra note 31 , at 460 . 
tainty to their general language, the Court, distinguishing them from the Sherman Act, held them void for uncertainty.

The Connally and Cline cases thus indicate that the common law precedents are of more than academic interest. They indicate that if the Sherman Act be construed to go beyond those precedents it must be held void for uncertainty. It is clear, therefore, that these precedents are of prine importance. Accordingly, they will be discussed first, followed by a consideration of cases decided under the Sherman Act, after which an attempt will be made to state what the present rule is.

\section{PRICE-FIXING AGREEMENTS AT COMMON IAW}

While the Supreme Court thus assumed in the Connally and Cline cases that the rule established at common law was reasonably certain, the task of determiming what that rule is, at least on the subject of price-fixing agreements; is not and has not been an easy one. The confusion and uncertainty as to what the view prevailing at common law on this subject is and was is nowhere better illustrated than by the fact that within a space of five years two very able federal circuit judges found occasion to review the common law authorities at great length and with great care, and yet came to precisely opposite conclusions as to what they held. Thus in United States v. TransMissouri Freight Ass' $n{ }^{36}$ decided in 1893, Circuit Judge Walter $\mathrm{H}$. Sanborn concluded that these authorities supported the view that price-fixing agreements were not unlawful per se at common law but were unlawful if, and only if, the agreement were otherwise shown to result in an undue or unreasonable restraint of trade; and that undue or unreasonable restraint is negatived where a price-fixing agreement is entered into for the purpose of eliminating ruinous or unhealthy competition or establishes only reasonable prices. But in United States v. Addyston Pipe \& Steel Co. ${ }^{37}$ decided in 1898, Judge (later Chief Justice) Taft, after a review of virtually the same authorities, concluded in effect that all price-fixing agreements are unlawful in themselves at common law "however reasonable the prices they [the parties thereto] fixed, however great the competition they had to encounter, and however great the necessity for curbing themselves by joint agreement from committing financial suicide by illadvised competition," adding: "... we do not think that at common

36 Supra note 11.

37 Supra note 27, at 291. 
law there is any question of reasonableness open to the courts with reference to such a contract." 38 This conclusion was based upon the broader premise that at common law all contracts restraining competition which were not ancillary to some other lawful contract were unlawful per $s e .^{30}$ It happened that many subsequent writers ${ }^{40}$ and the United States Supreme Court ${ }^{41}$ were more impressed with Taft's review and conclusion than they were with Sanborn's, and this has given rise to the frequent assertion that all price-fixing agreements are unlawful per se at common law. But notwithstanding the frequency with which that assertion has been made and the eminence of many of those who have made it, it is believed that an analysis of the authorities will show that this view of the common law cannot be supported. Certainly it cannot be said to represent the present view of the English courts. It is also clear that it does not represent the prevailing American view. What is even more important, it did not represent the view prevailing in either country at the time the Sherman Act was enacted. In view of the fact that the Supreme Court finally came around to the view that Congress intended to adopt the rule declared by the common law precedents on contracts and coinbimations in restraint of trade, it would seem that the state of the common law on this subject at the time the Sherman Act was enacted in 1890 is, if not absolutely controlling, at least a pertinent fact which should be very persuasive on the question of the proper inter-

38 Ibid. at 293.

$39 \mathrm{Ibid}$. at 279-282. Handler, op. cit. supra note 20 , at 19 , argues that this view and Taft's conclusion from it are correct beyond any question.

40 Oppenaemr, Cases on Trade Regulation (1936) 19; Taft, The Antr-Trust Act and tHe SUprede Court (1914) 20; Thornton, Codminattons In Restratnt of TrADE (2d ed. 1928) § 52; Dickinson, The Anti-Trist Laws and the Self-Regulation of Industry (1932) 18 A. B. A. J. 600, 601; Handler, op. cit. supra note 20, at 19; Oliphant, Trade Associations and the Law (1926) 26 CoL. L. Rev. 381, 384; Podell, Our Anti-Trust Lares and the Economic Situation (1931) 17 A. B. A. J. 254, 257; Pope, op. cit. supra note 20, at 167, 178; Shroder, Price Restriction on the Re-sale of Chattels (1911) 25 HaRv. L. Rev. 59, 66; Watkins, loc. cit. supra note 20; Wilgus, The Standard Oil Decision (1911) 9 Mxcr L. Rev. 643, 662; Notes (1932) 32 CoL. L. Rev. 291, 295; (1933) 19 VA. L. REV. 851, 859. Handler, loc. cit. supra, finds that the "substantial accuracy" of Taft's examination of the common law authorities "has never been successfully challenged." For writers taking a contrary view, see Allen, Criminal Conspiracies in Restraint of Trade at Common Law (1910) 23 HARv. L. Rev. 531, 541; Evans, The Supreme Court and the Sherman Anti-Trust Act (1910) 59 U. of PA. L. Rev. 61, 65; Foulke, Restraints on Trade (1912) 12 Cor. L. REv. 220, 232; Jaffe and Tobriner, op. cit. supra note 20, at 1171 ; Naujoks, op. cit. supra note 28 , at 418 .

41 United States v. Trenton Potteries Co., supra note 8, at 400, 401, n. 1; Cline v. Frink Dairy Co., supra note 31, at 461. 
pretation of the Act. If the common law authorities declared one rule before the Act and a different one after, it would seem apparent that it is more reasonable to say that Congress intended to adopt the former than the latter view. ${ }^{42}$ Accordingly, the authorities prior to the enactment of the Sherman Act will be discussed first, followed by a consideration of those decided afterwards.

\section{A. COMMON LAW AUTHORITIES PRIOR TO THE ENACTMENT}

OF THE SHERMAN ACT

\section{English Authorities}

That the English law very early assumed an attitude of hostility towards conspiracies, combinations, or agreements to fix or raise prices or wages is apparent from the numerous instances of early criminal prosecutions for conspiring to fix or raise prices ${ }^{43}$ or wages. ${ }^{44}$

$42 \mathrm{An}$ analogous problem is that raised by constitutional and statutory provisions adopting the "common law" as the rule of decision in the courts of tbe state. Frequently these provisions provide in express terms that the common law as it existed in 1607, 1775 , or at the time of the adoption of the provision in question is meant. See $12 \mathrm{C}$. J. 184. Where such statutes simply adopt "the common law" without further explanation, the rule is that the common law as it existed at the time the provision was adopted is intended. See Martin v. Superior Court (1917) 176 Cal. 289, 293, 168 Pac. 135, 136, L. R. A. 1918B 313, 316 ("we hold that our Legislature, in its use of the phrase 'common law' had in contemplation the whole body of tbat jurisprudence as it stood, influenced by statute, at the time when the Code section was adopted"); see also Smith Eng. Co. v. Rice (C. C. A. 9 th, 1938) 102 F. (2d) 492, 497 (similarly construing Montana law). The conclusion that the common law as declared by decisions in existence at the time the Sherman Act was enacted would also find support in the well known rule of statutory construction that when a statute is incorporated in another statute by reference subsequent amendments to the incorporated statute are not applicable to the incorporating statute. See United States v. McMurtry (W. D. Ky. 1933) 5 Fed. Supp. 515, 517, and cases there cited. See also Boudin, op. cit. supra note 29, at 1332.

43 In 1298, coopers were convicted of passing an ordinance "that no one should sell a hoop, formerly sold at $1 / 2 \mathrm{~d}$. and $3 / 4 \mathrm{~d}$., for less than $1 \mathrm{~d}$. . . " Thomas, Calendar or Earix MaxoR's Court Rolus of the City of London 1298-1307 (1924) 1. Judgment was rendered that "they he committed to gaol." Ibid. In 1300 skinners were attached to answer for passing an ordinance raising the price for dressing furs from $5 \mathrm{~d}$. to $6 \mathrm{~d}$., but the case was settled by agreeement of the skinners to reduce their prices. Ibid. at 92 . In the same year chandlers were indicted "for making an agreement amongst themselvesto-wit, that none of them should sell a pound of candle at less than another." LEET JuRISDiction IN Norwich (5 Pub. Selden Soc. 1891) 52. Eight were fined. In 1303 fruiterers were summoned to answer the inayor and aldermen "for having made a confederacy between them, strengthened by oath, that none of them would buy the fruit of any garden within London or without before the Feast of the Nativity of St. John the Baptist (24 June), so that they might then have their fruit as it were for nothing." Thomas, op. cit. supra, at 157. It appears from one of the Year Books that in 1353 matters to be inquired of by the inquests of office in the King's Bench included conspiracies "Also of merchants who by covin and alliance among themselves, in any year put a 
It is not clear, however, and probably never will be clear, whether these prosecutions were based on the common law or statute, so that they lend but little, if any, aid in determining what the early common law was. They do reveal, however, that public opinion even in

certain price on wools, which are to be sold in the country, so that none of them will buy, or otherwise pass in the purchase of wools beyond the certain price which they themselves have ordained to the great impoverishment of the people." Lib. Ass. (1353) Y. B. $27 \mathrm{Edw}$. III, 138. In 1381 spurriers were indicted on the charge that they had "made a covin and confederacy ... and ordained that none of them should make a quartern of spurs for less than $20 d$ nor take less than $2 s$ for the polishing of the same under penalty of perjury." Thomas, Carendar of Plea and Memoranda Rolis of the City OF LoNDoN, 1364-1381 (1929) 291.

44 In 1299 a carpenter was charged with gathering together a parliament of carpenters at Mile End, where they bound themselves by corporal oath not to observe an ordinance fixing their wages. Thomas, Carendar of EarLx Mayor's Court Rours of tHe CITY of LoNdoN 1298-1307 (1924) 25. In 1303 servant workmen in cordwainery were forbidden to "hold any meeting to make provision which may be to the prejudice of the trade and to the detriment of the common people...." 2 LIBER CUSTUMartum (Rolls Series) 541. In 1349 a number of bakers' servants were indicted for a conspiracy not to work except at double and treble the wages formerly given. George, The Combination Laws Reconsidered (1927) 1 Econ. Hist. 214, 223. In the same year a bill of complaint was brought against a number of cordwainers' servants for entering into a conspiracy not to serve except by the day and on their own terms. Ibid. at 224. In 1365 there was an attachment against several cordwainers for "rebelling against the masters of the mistery" and they were liberated after payment of a fine with a warning by the court "not to join in covins and confederacies in the future." Thomas, Calendar of Plea and Memoranda Roris of THE CiTY of London, 1364-1381 (1929) 22-23. In 1366 a jury found several fullers guilty "of forming a confederacy, calling out the working fullers and committing assault by contumelious words. . ." Ibid. at 54. In the same year, Flemish weavers were forbidden by the court "to hold any covins, leagues or assemblies in future, or to levy any subsidies from the inen of their mistery except on behalf of the infirm, blind and lame." Ibid. at 66. In 1383 a proclamation of the mayor of London forbade all "congregations, covins and conspiracies," except with leave of the mayor. Ritex, Memoriats of London and London LIFE (1868) 480. See also The Mirror of JUSTICES ( 7 Pub. Selden Soc. 1893) 40, where in the thirteenth century the hundred court was directed to inquire "Of all manner of conspirators. . . ." In 1387 journeymen cordwainers in London were charged with making an illegal fraternity contrary to the proclamation of 1383. RHEX, op. cit. supra, at 495. In 1396 the master saddlers of London complained to the mayor and aldernen of London that "under a certain feigned colour of sanctity, unany of the serving inen in the trade had influenced the journeymen among them, and had formed covins thereon, with the object of raising their wages greatly in excess." Ibid. at 543 . The council ordered that "the serving men in the trade aforesaid should in the future be under the governance and rule of the masters of such trade; ... and that in the future they should have no fraternity, meetings, or covins ... under a penalty etc." Ibid. at 544. In 1706 six cloth dressers of Leeds agreed not to work for any master below a certain wage and were heavily fined by the Leeds Sessions. See Heaton, The Assessment of Wages in the West Riding of Yorkshire in the Seventeenth and Eighteenth Centuries (1914) 24 EcoN. J. 218, 233. The writer last cited shows that statutes of this period fixing wages were regarded as fixing only maximum wages, leaving the parties free to bargain for wages below the maximum. 
this early period was opposed to such conspiracies and agreements. Further evidence of this is found in the form of complaints to Parliament because of such activities. ${ }^{45}$

Starting in with the Ordinance of Conspirators in $1304,{ }^{46}$ and extending down to the statute of 40 George III in $1800,{ }^{47}$ a long series of statutes was enacted aimed at curbing agreements or conspiracies to fix or raise prices or wages. Thus the Ordinance of Conspirators of 1304, although not expressly prohibiting such conspiracies was apparently regarded as doing so $^{48}$ and inaking them criminal. In 1360 a statute ${ }^{49}$ forbade and made illegal and void all confederacies of masons to violate the statute of laborers, and made participation therein a crime. In 1363 a statute ${ }^{50}$ prohibited grocers from conspiring or agreeing to sell only merchandise which was scarce and to withhold abundant merchandise from the market until it became

45 In 1320 fishmongers complained to Parliament of a confederation among other fishmongers that fish should no longer be sold by retail on a particular wharf. 1 Ror. PARL. 370a. In 1347 grievance was made against a confederacy of merchants who bad farmed the King's wool. 2 ibid. 170b. In 1376 burgesses complained that the counbinations of merchant strangers were to blame for greatly enhancing the price of all sorts of foreign merchandise. 2 ibid. 332 (59). In 1415 Parliament was asked to supervise the dyers of Coventry who had confederated to raise the cost of dyeing. 4 ibid. 75a. Complaints other than to Parliament were also made. An interesting example of the latter occurred in 1587 to 1589 when complaint was made by the writer of $A$ Discourse of Corporations as follows: "For these Corporacions, tradinge in trothe in conspiracies, being sworne to kepe secrete the ordinaunces and devises of theire fraternities, confederat not onely at what prices they shall sell the wares that they bringe, which is aparaunt by the small difference of prices in all theire grosse sales and retaile, but also what prices they shall giue for theire comodities at lome, as to the Clothier for his clothe, others for theire wooll, lead, tyn, etc., whereby they are hecome Lordes ouer all the Counoditics of this Realme, for no man may buy or sell but as they will; for they have provided by theire constitucion ne quis pluris ne quis minoris, that no man should sell for lesse or buy for more; which thoughe they will denye as a thinge not tollerable in any Comonwelthe, it is aparaunt in theire accions, for occupyinge in consorte they buy at one price and sell at one price, as privie one to anothers doinges. . . " TAWNEY and PowER, TUDOR ECONOMIC DOCUMENTS (1924) 271.

$4633 \mathrm{EDw} . \mathrm{I}(1304)$ st. 2.

47 C. 106. An interesting forerunner of these statutes was the Roman Law edict of Emperor Zeno, issued to the Practorian Prefect of Constantinople in 483 A.D. (Code IV, 59) which provided: "We command that no one may presume to exercise a monopoly of any kind of clothing, or of fish, or of any other thing serving for food, or for any other use, whatever its nature may be ... nor any persons combine or agree in unlawful meetings, that different kinds of merchandise may not be sold at a less price than they may have agreed upon among themselves.' "Translated by A. H. Marsh in Commercial "Trusts" in Rome (1888) 8 Car. L. T. 299; Note (1889) 23 Axr. L. Rev. 261. See also 4 BL. CoMm. * 159 .

485 GEO. IV (1824) c. 95 so regarded the Ordinance of Conspirators.

4934 EDW. III (1360) c. 9.

$5037 \mathrm{EDW}$. III (1363) c. 5 . 
scarce and made such action criminal. In 1424 a statute ${ }^{51}$ declared illegal and void all confederacies of masons to violate the statutes of laborers. In 1436 a statute, ${ }^{52}$ after reciting that many ordinances had previously been made in confederacy "for their singular profit," provided that ordinances of guilds, fraternities or companies nust first be "approved for good and reasonable" by the justices of the peace.

In 1548 the most important of these early statutes was enacted, that of $2 \& 3$ Edward VI. ${ }^{53}$ This statute, after reciting that "divers sellers of victuals, not contented with moderate and reasonable gain ... have conspired and covenanted together to sell their victuals at unreasonable prices. ... And likewise artificers, handicraftsmen and labourers have made confederacies and prormses," made it a criminal offense "if any butchers, brewers, bakers, poulterers, cooks, costermongers ${ }^{64}$ or fruiterers, shall . . . conspire, covenant, promise or make any oaths, that they shall not sell their victuals but at certain prices ... or if any artificers, workmen or labourers do conspire, covenant, or promise together, or make any oaths, that they shall not make or do their works but at a certain price or rate..." ${ }^{55}$ It is quite clear that under this act price-fixing agreements by those described therein and all wage-fixing agreements were unlawful per se. The act illustrates the tendency at this time to regard conspiracies or agreements to fix prices or wages as being governed by the same principle and as being equally unlawful. ${ }^{56}$ This tendency continued for a long time after 1548 .

613 HEN. VI (1424) c. 1.

5215 HeN. VI (1436) c. 6. The act was re-enacted by 19 HEN. VII (1503) c. 7, the preamble of the latter reciting that the reason for the former act was that masters, wardens, and people of guilds, fraternities, and other companies corporate oftentimes make many unlawful and unreasonable ordinances, "as well in prices of wares as other things...."

53 2 \& 3 EDW. VI (1548) c. 15.

54 A costermonger is defined as "An apple seller; a hawker of fruit or vegetables from a street stand, harrow, or cart." WEBSTER, NEW INTERNaTTONaL DICTIONARY (2d ed. 1934) 602.

552 \& 3 EDw. VI (1548) c. 15. The penalties for violating the act were progressively larger for second and third offenders. The penalty for the first offense was ten pounds fine or twenty days in jail; for the second offense, twenty pounds or the pillory; for the third offense, forty pounds "or else shall sit on the pillory and lose one of his ears, and also shall at all times after that be taken as a man infamous, and his saying, depositions or oath not to be credited at any time in any matters of judgment." Ibid.

EO This tendency is also noted in LaNDIS, CaSes on LaBor Law (1934) 8; George, op. cit. supra. note 44 , at 222 . George states that combinations to raise the prices of commodities "were regarded in the same light as combinations to raise the price of labour." Ibid. 
In 1552 a statute ${ }^{57}$ was passed punishing forestalling, engrossing, and regrating, and defining forestalling in such a way as apparently to make subject to the penalties prescribed by the act conspiracies or agreements to raise the price of articles coming to a market or fair, for it prohibited persons from nraking "any motion by word, letter, message or otherwise, to any person or persons, for the inhancing of the price or dearer selling of inerchandise, victual, or any other thing whatsoever." ${ }^{158}$ While this provision was seemingly limited in scope since it applied only to goods moving to a market or fair, it has been cited by Sir Williain Holdsworth as evidence of a rule that all combinations to raise the price of victuals ${ }^{59}$ were unlawful at common law as a form of forestalling..$^{60}$

In 1662 a statute ${ }^{61}$ forbade, but apparently did not make crininal, orders or by-laws of the Corporation of Silk Throwers which "set any rates or prices whatsoever upon the throwing of silk. ..." In 1720 a statute ${ }^{62}$ made illegal and void all agreements between the journeymen tailors of London and Westminster and also inade participation therein a crime. In 1725 a statute ${ }^{63}$ made illegal and void all agreements, ordinances, or by-laws by woolcombers or weavers "for regulating or settling the prices of goods, or for advancing their

$575 \& 6$ EDw. VI (1552) c. 14, §§ 1-3. This was not the first statute relating to forestalling, regrating, and engrossing. Holdsworth states that the statute was designed to give precision "to an old branch of the common law, enforced by earlier statutes but never accurately defined." 4 HordswORTH, History of ENGLisH LAw (1924) 375, referring to 25 EDw. III (1350) st. 4, c. 3;27 EDw. III (1353) st. 2, c. 11; 28 EDw. III (1354) c. 13, § 3. The Assize of Bread, 51 Hev. III (1266) st. 1, seems to be the eartiest statute mentioning forestalling. It also mentions regrating. Another statute not mentioned by Holdsworth was that of 37 EDw. III (1363) c. 5. See Herbruck, Forestalling, Regrating and Engrossing (1929) 27 MICH. L. REv. 365.

585 \& 6 EDw. VI (1552) c. $14, \S 1$.

59 Holdsworth seemingly overlooks the fact that forestalling was not confined to victuals but extended to "merchandise, victual, or any other thing whatsoever."

604 HordsworTH, op. cit. supra note 57, at 377. This view is taken by the Court of Appeals of Maryland in Klingel's Pharmacy v. Sharp \& Dohune (1906) 104 Md. 218, 230, 64 Atl. 1029, 1030. In State v. Eastern Coal Co. (1908) 29 R. I. 254, 70 Atl. 1, a conspiracy among coal dealers to fix prices was regarded as punishable as the common law crime of "engrossing"-an obviously incorrect characterization. See 5 \& 6 EDw. VI (1552) c. 14, § 3. Cf. Cousins v. Smith (1807) 13 Ves. 542, which while not too clear a case, apparently regards a price-fixing agreement as not constituting either forestalling, engrossing, or regrating. Herbruck, op. cit. sipra note 57 , at 379 , eites an instance of where the House of Commons treated a combination of millers to fix the price of corn brought to the market as engrossing.

6113 \& 14 CAR. II (1662) c. 15, § 10.

627 Geo. I (1720) st. 1, c. 13.

6312 GEo. I (1725) c. 34. 
wages," and also made participation therein a crime. In the same year a statute ${ }^{6 .}$ was passed for the avowed purpose of preventing "all unlawful combinations amongst any brickmakers or tilemakers within fifteen miles of the city of London in order to advance or enhance the price of bricks or tiles," apparently making such combinations criminal. In 1749 a statute ${ }^{65}$ made illegal and void all agreements, ordinances or by-laws for regulating or settling the prices of goods or for advancing wages of journeymen dyers, journeymen hat pressers, and all persons employed in and about woolen manufactories, and also such agreements, ordinances, or by-laws when made by journeymen servants, workmen, or laborers employed in the making of felts or hats, or $m$ and about the manufactures of silk, mohair, hemp, flax, cotton mohair, or silk "or of any of the said materials mixed one with another." Violators of this statute were also subject to criminal prosecution. In 1788 a statute ${ }^{66}$ forbade and made criminal combinations to advance the price of coal. In 1795 a statute ${ }^{67}$ forbade "all contracts, covenants, and agreements whatever, in writing or not in writing ... by or between any journeymen paper makers ... for obtaining an advance of wages," and also subjected violators to criminal prosecution.

The last of this series of enactments were the statutes of 39 George III $^{\text {Bs }}$ and 40 George III ${ }^{69}$ in 1799 and 1800, respectively, which forbade "all contracts, covenants, and agreements whatsoever, in writing, or not $m$ writing ... by or between any journeymen manufacturers or other workmen, or other persons within this kingdom, for obtaining an advance of wages of them, or any of them...."

6412 GEO. I (1725) c. 35, as explained in 2 GEo. II (1729) c. 15.

6522 Geo. II (1749) c. 27 . See also 17 GEo. III (1777) c. $55, \& 3$.

6628 GEo. III (1788) c. 53, $\$ 2$. The statute provided that any number of persons "united in covenants or partnerships, or in any way whatsoever, consisting of more than five persons, for the purchasing of coals for sale, or for making regulations with respect to the manner of carrying on the said trade in coals" shall be deemed an unlawful combination to advance the price of coals and persons participating therem "shall be liahle to be punished by indictment or information for the same, in his Majesty's court of King's bench at Westminster." Ibid.

67 36 GEo. III (1795) c. 3. Another statute was enacted in 1797 (37 GEo. III, c. 123) which, while not of the same character as the statutes ahove listed, prohibited and penalized the making of oaths by nembers of an illegal society. While not framed for the purpose of preventing wage-fixing or price-fixing agreeinents but to prevent societies formed to stir up sedition and mutiny, it was later used to punish a conspiracy among laborers to raise wages where accompanied by the making of oaths. King v. Marks (1802) 3 East 157.

6839 Geo. III (1799) c. 81.

6940 GEO. III (1800) C. 106. 
The existence of so many statutes expressly invalidating and making criminal agreements, combinations, and conspiracies to fix or raise prices or wages would not unnaturally lead to the conclusion that such activities were neither illegal nor. criminal at common law, and such is the conclusion that has been made by many writers. ${ }^{70}$

On the other hand, a plausible argument can be and has been made to the effect that these statutes, and especially the earlier ones, are themselves evidence of and merely declaratory of common law primciples. Thus Dean Landis ${ }^{71}$ criticizes the position of the above writers stating that their approach "neglects to search for the aims of a society as they may be indicated by the policies expressed in statutes-statutes which are of themselves the gernninating source of "common law." Sir William Holdsworth" notes that "The lawyers' ideas as to what is legal and what is illegal 'at common law' are naturally coloured by ideas as to public policy which are constantly and repeatedly expressed in statutes." And he further declares that it is not surprising that after centuries of such legislation "the lawyers should suppose that there existed a set of common law primciples which made any kind of conspiracy in restraint of trade a criminal offence." 73 A recent very careful study of the problem in England has resulted in a like conclusion. ${ }^{74}$ The decision in King v. Waddington ${ }^{75}$ holding that notwithstanding the repeal, in

703 Stephen, History of the Crmminal Law of Engiand (1883) 210, where it is said: "I must add that $I$ am quite unable to understand why, if all combinations to raise wages were at common law indictable conspiracies, it should have been considered necessary to pass the long series of acts already referred to." Sayre took the same view, saying the whole doctrine that a conspiracy to commit a lawful act could he an indictable conspiracy at common law is "so manifestly founded upon misconceptions and erroneous applications of ambiguous statements that it is difficult to support." Sayre, Criminal Conspiracy (1922) 35 HARv. L. REv. 393, 409. Alderson, B., in Hilton v. Eckersley, supra note 13 , at 70, also took this view, as does the following writer: Boudin, op. cit. supra note 29, at 1324; Boudin, The Sherman Act and Labor Disputes: II (1940) 40 Cot. L. REv. 14, 31, et seq. Jaffe and Tobriner, op. cit. supra note 20, at 1167 , argue that all the cases prior to 1800 , hereafter reviewed, were referable to the statute of $2 \& 3 \mathrm{EDw}$. VI (1548) c. 15, and not the common law.

71 op. cit. supra note 56, at 4 et. seq.

72 HgLdswORTH, op. cit. suppra note 57 , at 470 .

73 Ibid. at 471.

74 George, op. cit. supra note 44; George, The Combination Laws (1936) 6 Econ. Hist. 172, 173.

75 (1800) 1 East 143. All previous statutes relating to forestalling, engrossing, and regrating were repealed in 1772 by $12 \mathrm{GEo}$. III, c. 71. See Herbruck, op. cit. supra note 57 , at 379 , for account of repeal. In 1844 a statute (7\& 8 VICr. c. 24) forbade the prosecution of forestalling, engrossing, or regrating as common law crimes. The act of 1844 was repealed by the Statute Law Revision Act [55 \& 56 VICT. (1892) c. 19], 
1772, of statutes making forestalling, engrossing, and regrating illegal and criminal, such conduct remained a crime at common law, strongly supports this view. But there is much additional evidence which establishes the correctness of this position almost conclusively. This evidence consists of the opinions of reported cases down to 1800. In order that this shall appear, these opinions will now be reviewed in some detail.

In Rex v. Starling ${ }^{76}$ decided in 1663 , an indictment charged certain brewers in London with a conspiracy to refuse to sell small beer. The court said by way of dictum that "the very conspiracy to raise the price of Pepper is punishable, or of any other Merchandise ...."Ti It is not entirely clear how the subject of pepper found its way into the court's opinion. However this may be, the dictum is very important as indicating the court's view of the law on this subject. A conspiracy to raise the price of pepper "or of any other Merchandise" would clearly not come within the statute of $2 \& 3$ Edward VI, hereinabove referred to, and accordingly the dictum could not have been based upon that statute and cannot, as has been argued, ${ }^{78}$ be regarded as referable to it. It seems referable to the common law alone, and to indicate an early common law hostility to conspiracies to raise

thereby leaving the present status of the question in some confusion. See Herbruck, op. cit. supra note 57, at 387. In Georgia forestalling, regrating, and engrossing are still punishable as statutory crimes, the offenses being defined in almost exactly the same way as found in the statute of 5 \& 6 EDw. VI (1552) c. 14. See GA. Code (1933) § 26-7404. The statute was enacted during the Civil War. Ga. Laws 1863-1864, No. 42. The Mississippi Antitrust Law condemns combinations "To engross or forestall a commodity." MISs. CODE ANN. (1930) $\S 3436$ (e). The Ohio Code makes criminal the act of forestalling "the market by spreading false rumors." OHIo ANN. CoDE (Throckmorton, 1930) $\S 13069$.

${ }^{76}$ (1663) $1 \mathrm{Keb}$. 650. Mr. Watkins asserted that horizontal price-fixing or agreements affecting prices were not common during the seventeenth and eighteenth centuries because with the decay of the guilds ambitious masters were extremely jealous of their independence and violent partisans of freedom of trade. Watkins, op. cit. supra note 20 , at 824. Cf., however, the reunarks of Adam Smith, writing in 1776, where such combinations are said to have then been not only common but inevitable He said: "PEOPLE of the sanie trade seldom meet together, even for merriment and diversion, but the conversation ends in a conspiracy against the public, or in some contrivance to raise prices. It is impossible indeed to prevent such meetings, by any law which either could be executed or would be consistent with liberty and justice." 1 SMUTH, WEALTH or Natrons (1789 ed.) 170.

$7 \tau 1 \mathrm{Keb}$. at 650 .

78 See Jaffe and Tobriner, op. cit. supra note 20 , at 1167 . This article erroneously refers to the statute of $2 \& 3$ Edvard VI as "forbidding the butchers, bakers, victuallers, artificers, workmen or laborers from conspiring to sell only at certain prices." Ibid. (Italics added.) Blackstone seems to make the same error. $4 \mathrm{BL}$. CoMoM. *159. 
the price of all merchandise. The dictum offers support for the view that agreements to raise the price of merchandise were per se illegal at common law at this time. Whether the dictum was confined to agreements directly fixing prices does not appear and cannot be determined.

Fifteen years later, in Freemantle v. Company of Silk Throwsters, ${ }^{79}$ the Court of King's Bench upheld a by-law of a company of silk throwers by which they agreed not to throw more than a certain number of spindles of silk per week, against the charge that it was illegal because in restraint of trade. The court resolved:

"That this is not a Monopoly, but a Restraint of a Monopoly, that none might engross the whole Trade; being rather to provide for an Equality of Trade, according to what is convenient, and good...."80

Here we find an agreement among competitors, not ancillary to any other contract, to limit the production of each-one which directly affects prices by raising them, and the court not only upholds it but finds it "convenient, and good." This case might be considered as some evidence that the dictum of Rex $v$. Starling was confined to agreements directly fixing prices and not those which result in raising them but not directly fixing them.

The next case-an Anonymous one decided in $1698^{81}$ - is very brief. The court granted leave to file an information against several plate-button makers, for combining, by covenants, not to sell under a set rate. Chief Justice Holt declared "It is fit that all confederacies, by those of trade to raise their rates should be suppressed." ${ }^{\prime 22}$ No reference is made to any statute, and obviously this agreement is not one within the terms of $2 \& 3$ Edward VI, ${ }^{83}$ or any other statute above referred to. It indicates that at this time the common law regarded all agreements directly raising prices as unlawful per se.

In King v. Journeymen-Taylors of Cambridge, ${ }^{84}$ decided in 1721, an indictment was returned against certain journeymen tailors of the

79 (1678) 1 Lev. 229.

80 Ibid.

81 (1698) 12 Mod. 248.

82 Ibid. (Italics added.)

83 Jaffe and Tobriner, op. cit. supra note 20 , at 1167 , erroneously assumed the contrary. Cf. Nelles, The First American Labor Case (1931) 41 YAxE L. J. 165, 196, contending that the basis of the decision was the statute against engrossing and forestalling. But see LANDis, op. cit. supra note 56, at 9, n. 54. Cf. 4 HoldsworTH, op. cit. supra note 57 , at 377 .

84 (1721) 8 Mod. 10. 
town of Cambridge charging a conspiracy to raise wages. While a statute $^{85}$ fixed wages, and the tailors had apparently agreed to demand more than the statutory wages, the court placed no reliance on this feature for it said: ${ }^{86}$

"The indictment, it is true, sets forth, that the defendants refused to work under the wages which they demanded; but although these might be more than is directed by the statute, yet it is not for the refusing to work, but for conspiring, that they are indicted, and a conspiracy of any kind is illegal, although the matter about which they conspired might have been lawful for them, or any of them, to do, if they had not conspired to do it, as appears in the case of The Tubwomen v. The Brewers of London." 87

It was argued that the indictment was defective because it failed to refer to the statute under which it was brought and in particular to the statute of $2 \& 3$ Edward VI, or the statute of 7 George I, enacted the previous year. ${ }^{8 s}$ But the court overruled the objection saying: "This indictment need not conclude contra formam statuti, because it is for a conspiracy, which is an offense at common law." 89 Perhaps no case in the books has been subjected to as much discussion as this as to the exact basis and extent of its holding. Notwithstanding the plain language of the opinion that the indictment was upheld as charging a common law offense, writers have set up the claim that the case is in truth based upon one of the two statutes referred to in the opinion or some other statute, and not the common law..$^{90}$ And American courts and lawyers have sought to minimize the authority of the case by attacking the accuracy of the reporter of the cases in

855 ELIZ. (1562) c. 4.

868 Mod. at 11.

87 Commonly assumed to be Rex v. Starling, supra note 76. See LANDIs, op. cit. suppra note 56, at 11, n. 71; Purrington, The Tubwomen v. The Brewers of London (1903) 3 Cor. L. Rev. 446.

887 GEO. I (1720) c. 13, making it criminal for journeymen tailors of London and Westminster to enter into agreements to raise their wages. As the case involved Cambridge and not London or Westminster, this statute was not applicable in any event. See LaNDrs, op. cit. supra note 56, at 11 . Mr. Landis gives no reason why the statute of 2 \& 3 Edward VI was not applicable, however.

$80 \mathrm{~S}$ Mod. at 12. (Italics added.)

90 Wright, the Law of Crminat Conspiractes and Agreemanis (1873) 52; Nelles, loc. cit. supra note 83; Sayre, op. cit. supra note 70, at 403. Cf. Jaffe and Tobriner, op. cit. supra note 20, at 1167, n. 11. See also Aetna Ins. Co. v. Commonwealth (1899) 106 Ky. 864, 882, 51 S. W. 624, 628; Commonwealth v. Hunt (1842) 45 Mass. (4 Metc.) 111, 122 ; Taft, J., in Moores \& Co. v. Bricklayers' Union (Cimcinnati Super. Ct. 1887) 10 Ohio Dec. 665, 673, all taking the same view. 
8 Modern, ${ }^{91}$ in which volume the case appears. ${ }^{92}$ It would seem difficult to challenge the case on either of these grounds, however, ${ }^{93}$ particularly in view of the fact that other cases both prior and subsequent to the case announced the same rule.

Thus im King $v$. Norris, ${ }^{94}$ decided in 1758 , an information was granted against several proprietors of salt works in Droitwich for a conspiracy to raise the price of salt by entering into an agreement whereby they bound themselves, under a penalty of $£ 200$, not to sell

91 English judges and lawyers have frequently criticized this volume. In Rex v. Williams (1757) 1 Burr. 385, 386, 8 Modern is called "A miserably bad Book, entitled 'Modern Cases in Law and Equity." The comment was made by Sir William Burrows, the reporter. In Rex v. Vipont (1761) 2 Burr, 1163, as further explained in King v. Harris (1797) 7 T. R. 238, 239, Wilmot, J., said of this book: "That case is reported in Modern Cases in Law and Equity (8 Mod. 175): but is totally mistaken there, as indeed are nine cases of ten in that book." In Rex v. Harrison (1762) 3 Burr. 1322, 1326, Sir William Burrows said in a footnote: "Wannell's Case being here cited from $8 \mathrm{Mod} .267$. The Court treated that Book with the Contempt it deserves; And they All agreed that the Case was wrong stated there. (I mean the old Edition of that Book.)" Mr. Leach, in his preface to the second edition of 8 Modern, after observing that the first edition "must have been exceedingly imperfect and erroneous" stated that he had done his best "to supply the defects of the former wretched edition."

${ }^{92}$ See The New York Journeymen Cordwainers Case (N. Y. Ct. of Gen. Sess 1809) Yates Sel. Case 111, 162; Master Stevedores' Ass'n v. Walsh (C. P. N. Y. Co. 1867) 2 Daly 1, 6; People v. Cooper (N. Y. Ct. of Gen. Sess. 1836) 4 Commrons and Grrmore, DocumIentary History of Amertican Industrial SociEty (1910) 277, 296; Nelles, op. cit. supra note 83, at 197. Mr. Landis concludes, correctly, it would seem, that "though the Modern Reports may be justly so criticized in general terms, more evidence of their fallaciousness in this instance is demanded in order to substantiate such an assault." LANDIs, op. cit. supra note 56, at 11 .

${ }^{83} \mathrm{Mr}$. Landis is strongly of this view. Ibid. Stephen concludes that Wright's analysis of the case, loc. cit. supra note 90, "appears doubtful." 3 STEPHEN, op cit. supra note 70, at 209. In Hedges and Winterbottod, The Legar History OF TrAdE UNIONISM (1930) 13, the authors, after a careful and thorough review of the question, conclude that although the theory that conspiracies to raise wages were criminal at common law "is not upheld by rehiable authority," nevertheless such theory "appears to have been generally accepted in the years immediately preceding 1799." Winfield does not dispute the authority of the case and indicates it condemns conspiracies to raise wages at common law. Early History of Criminal Conspiracy (1920) 36 L. Q. REv. 359,375 . Holdsworth seems to take the same view. Industrial Combinations and the Law in the Eighteenth Century (1934) 18 MINN. L. REv. 369, 374. Chief Justice Savage also took this view and cited many other examples of conspiracies to raise wages being held indictable as common law crimes in People v. Fisher (N. Y. 1835) 14 Wend. 9, 16, (1886) $28 \mathrm{Am}$. Dec. 501, 505. The terms of the statutes repeahing the laws forbidding combinations to raise wages also support the theory that such combinations were common law crimes, for they expressly prohibited prosecution of conspiracies or agreements of laborers or masters to fix wages as common law crimes. See 5 GEo. IV (1824) c. $95, \S 2 ; 6$ Gro. IV (1825) c. $129, \S 2$.

84 (1758) 2 Keny. 300. 
salt under a certain price, which exceeded the price then current. In condemning the agreement Lord Mansfield declared:

"... that if any agreement was made to fix the price of salt, or any other necessary of life (which salt emphatically was), by people dealing in that commodity, the court would be glad to lay hold of an opportunity, from what quarter soever the complaint came, to shew their sense of the crime; and that at what rate soever the price was fixed, high or low, made no difference, for all such agreements were of bad consequence, and ought to be discountenanced." 95

The reporter said that Lord Mansfield also "mentioned an indictment, upon one of the last home-circuits, against the bakers of the town of Farnham, for such an agreement."

It is important to note in connection with King $v$. Norris that we find the court for the first time condemning in unmeasured terms all price-fixing agreements with respect to necessaries irrespective of any other consideration. Previously, as we have seen, condenmation was limited to price-raising agreements. It is also important to note that the case was not one referable to the statute of 2 \& 3 Edward VI, as has been contended. ${ }^{9 \tau}$ Salt manufacturers do not come within that statute. Nor does it seem referable to any other statute. ${ }^{98}$ The decision seems plainly to condemn all price-fixing agreements with respect to necessaries as per se unlawful at common law, even though the case actually involved only an agreement to raise prices. It was so interpreted in King $v$. Waddington, considered infra.

The rule of King $v$. Norris was extended by dictum to "any articles of trade" in The King v. Eccles, ${ }^{99}$ in 1783, where an indictment

95 Ibid. (Italics added.)

86 Ibid. at 301.

97 Allen, op. cit. supra note 40, at 535; Jaffe and Tobriner, loc. cit. supra note 20 .

98 Allen, op. cit. sitpra note 40 , at 535 , contends that the case may be referable to $37 \mathrm{EDw}$. III (1363) c. 5, or 25 HEN. VIII (1533) c. 2. The contention is unsound. The former statute is discussed above and deals only with conspiracies between grocers to sell only dear merchandise and hold abundant merchandise from the market until an artificial scarcity was created. The statute of 25 HeN. VIII (1533) c. 2, after reciting that prices had been unreasonably enhanced due to engrossing and regrating (not forestalling) gave officers of the king the power to fix reasonable prices of victuals "necessary for man's sustenance," whenever complamt was made "of any enhancing of prices of such victuals, without ground or cause reasonable." No criminal penalties were prescribed.

In King v. Waddington, supra note 75, Lord Kenyon declared the case to be referable to the common law. So did Chief Justice Savage of the New York Supreme Court in People v. Fisher, supra note 93 . See also Landis, op. cit. supra note 56, at 9, n. 54.

99 (1783) 1 Leach 274. 
charged a conspiracy to impoverish plaintiff by preventing him from working at his trade. It was contended that the means by which the intended result of the conspiracy was brought about should have been alleged. In overruling the contention Lord Mansfield said by way of illustration:

"... persons in possession of any articles of trade may sell them at such prices as they individually may please, but if they confederate and agree not to sell them under certain prices, it is conspiracy; so every man may work at what price he pleases, but a combination not to work under certain prices is an indictable offense." 100

A similar dictum is found in the case of The King v. Mawbey, ${ }^{101}$ decided by the Court of King's Bench in 1796, where in an indictment for conspiring to certify to the court as true a certificate which was false the court said:

"As in the case of journeymen conspiring to raise their wages: each may insist on raising his wages, if he can; but if several meet for the same purpose, it is illegal, and the parties may be indicted for a conspiracy." 102

Further supporting this dictum are many other instances of common law prosecutions of laborers for conspiracy to raise their wages decided during the period between 1760 and $1800 . .^{103}$

In Smith v. Scott, ${ }^{104}$ decided by the House of Lords on appeal from Scotland in 1798, six chaise hirers or postmasters had entered into an agreement to fix a certain rate, higher than previously charged for posting, it appearing that they could make no profits at the previous rate. The Procurator Fiscal of the County of Edinburgh presented a complaint against them to the justices of the county accusing them of an illegal and improper combination to raise the fare of posting. The basis of the power of the justices of the peace in the premises seems to have been an immemorial custom of the justices exercising power to punish conspiracies of postmasters and innkeepers to exact extortionate rates. The Court of Session condemned the combination and the House of Lords dismissed an appeal from this ruling, saying:

100 lbid. at 276.

101 (1796) 6 T. R. 619.

102 Ibid. at 636 .

103 For a list of unreported lower court prosecutions of laborers for conspiracies to raise wages, between 1760 and 1800 , resting apparently on the common law, sec LANDIS, $o p$. cit. supra note 56, at 12. For other such instances, see CHExNEY, IndustriaI AND SOCIAL History OF ENGLAND (1920) 282.

$104_{4}$ Craig. \& St. 17. 
"By this, your Lordships know, they were imposing a law to demand from the public, a certain and fixed rate for posting, which was illegal and unwarrantable. By this combination, they were subjected to the jurisdiction of the justices, as is not controverted. The case is very different, whether an individual might or might not ask what rate for posting he thought fit; but he must not make a party business of it."105

While the case is not a common law case since it arose under the Scottish law, the additional remark of the House of Lords that "In this country, the proceeding would have been by presentment to the grand jury, and indictment, which would no doubt have been found against the parties in the combination, who would have been punished"106 indicates that the House regarded an agreement to raise prices as indictable at this time, and since cases prior to this had made such rule referable to the common law rather than statute presumably the court had such cases in mind and approved their holding.

In King v. Waddington ${ }^{\mathbf{1 0 7}}$ defendant was indicted and convicted of circulating false rumors for the purpose of raising the price of hops and of buying hops for the purpose of withholding them from the market and exacting an unreasonable price for them. The court held that the defendant was guilty of engrossing and forestalling; that notwithstanding the repeal of the statutes on this subject these offenses remained crimes at common law. In the course of the opinion, Lord Kenyon referred to and approved King v. Norris, without citing it, and indicated that it was a case referable to the common law. He said:

"Again, it is urged that the quantity purchased cannot constitute the offence of engrossing, unless it bear such proportion to the consumption of the whole kingdom as will affect the general price. This objection is new to me; but if the opimions of Lord Mansfield, Mr. Justice Dennison, and Mr. Justice Foster ${ }^{108}$ are deserving of attention, there is as hittle in that objection as in the rest. I well remember an information moved for before them against certain persons for conspiring to monopolize or raise the price of

105 Ibid. at 20.

106 Ibid.

107 Supra note 75.

${ }_{108}$ The names of the justices participating in the decision in King v. Norris, supra note 94, do not appear from the report of the case. It does appear therefrom that justices other than Lord Mansfield participated, however, and cases decided at or around that time indicate that Justices Dennison, Foster, and Wilmot were the other members of the court. There can be little doubt, therefore, that Lord Kenyon intended to refer to King. v. Norris. Lord Kenyon was himself the reporter of the volume in which King v. Norris ultimately appeared. This volume was not published until 1825 , and this accounts for Lord Kenyon not citing the case by name and volume. 
all the salt at Droitwich. They had no doubt of its constituting an offence, although it was not pretended that these persons had endeavoured to engross all or any considerable part of the salt in this kingdom. Nor was it questioned but that the monopolizing of salt was an offence at common law." 109

While the remarks of Lord Kenyon with respect to King v. Norris are not entirely accurate in that the case was not one of engrossing, the opinion indicates his strong belief that that case was referable to the common law and that alone, and that up to this time the common law condemned all price-fixing agreements as unlawful per se and criminal, regardless of the extent to which the parties thereto did or did not control the market.

Froin the foregoing review, it would seem clear enough that down to the start of the nineteenth century agreements which directly fixed prices or wages were regarded as unlawful per se and also criminal at common law, whether or not the parties thereto controlled the market or any part thereof, and that the rule was applied indiscriminately both to price-fixing and wage-fixing agreements. On the other hand, the only case involving an agreement directly affecting prices without directly fixing them, i.e., the Freemantle case, upheld such an agreement, thereby indicating that up to this time such agreements were not regarded in the same light as agreements directly fixing prices. While it is true that the cases invalidating price-fixing agreements did not say expressly that they did so because the agreements restrained trade or competition, it would seem clear that such was the real objection motivating the decisions in such cases. ${ }^{110}$

109 King v. Waddington, supra note 75 , at 156.

110 Several writers make much of this fact and from it argue that the cases just considered are not referable to any common law principle against restraint of trade but to some other undefined principle of illegality. In a recent article by $\mathrm{Mr}$. Boudin this thesis is developed at great length in support of the theory that agrcements of laborers to raise wages never were held unlawful restraints of trade at common law, and so should not have been held to be such under the Sherman Act. Boudin, op. cit. supra note 70, at 31 et seq. The position would seem incorrect for two reasons: (1) It is impossible to beheve that the courts did not bave in mind concepts of restraint of trade when they condemned conspiracies and agreements fixing prices and yet the courts, as well as Parliament, as noted above, regarded wage-fixing agreements and price-fixing conspiracies in the same light and governed by the same principle. Sce The King $v$. Eccles, supra note 99, and the statute of $2 \& 3$ EDw. VI (1548) c. 15. (2) It is contrary to the views of English courts which regard the cases as based on the policy against restraints of trade. Thus in King v. Turner (1811) 13 East 228, 231, Lord Ellenborough said of the case of The King v. Eccles: "And the case of The King. v. Eccles and Others was considered [by the court] as a conspiracy in restraint of trade." (Itahics added.) The decision in Hilton v. Eckersley, supra note 13, is itself a recognition tbat the vice 
With the coming of the nineteenth century the law on this subject took quite a different turn although the development was not the same in cases involving agreements fixing prices as it was in cases involving agreements fixing wages. With respect to the latter, labor unions were particularly imterested in changing the rule previously declared, since that rule in effect made their very existence a crime. ${ }^{111}$ They took their fight to Parliament, and by a series of enactments progressively had it declared by statute that agreements fixing wages were neither criminal nor illegal, and obtained the repeal of the many statutes to the contrary above referred to. ${ }^{112}$

of wage-fixing agreennents was that they restrained trade, and that they ceased to be criminal only because of the statute of 6 Geo. IV (1825) c. 129. Crompton, J., in that case lent additional support to this view. See $6 \mathrm{E}$. \& B. at 53. In CHeYNex, op. cit. supra note 103 , at 280 , it is said (referring to the law at the start of the nineteenth century): "The ordinary and necessary action of trade unions was illegal by the Common Law also, under the doctrine that combined attenpts to influence wages, hours, prices, or apprenticeship were conspiracies in restraint of trade, and that such conspiracies had been repeatedly declared to be illegal." (Italics added.) In 2 HordswortH, op. cit. supra note 57 , at 469 , it is said that combinations to raise wages were regarded as in restraint of trade in the fourteenth and fifteenth centuries, although express language to this effect is not found in cases or statutes.

111 George states that the Combination Laws enacted in 1799 and 1800 were without any substantial effect; that "after, as before, the Act, prosecutions continued to be made at common law," and the act was a dead letter. George, loc. cit. supra note 74. Mr. Landis agrees with this conclusion, saying that while there were many prosecutions under the Combination Act of $\mathbf{1 8 0 0}$ there were many "generally inore severe" prosecutions under the common law during that period. LANDIS, op. cit. supra note 56, at 15 .

112 The history of the movement for repeal of the Combination Laws and to legalize nornal activities of labor unions is well described in LANDis, op. cit. supra note 56, at 16 et seq. The first step was the Act of 1824 [5 Geo. IV (1824) c. 95] which expressly repealed those statutes referred to above which prohibited combinations to raise wages and expressly provided (\$2) that laborers who shall enter into any combination to obtain an advance or to fix the rate of wages "shall not therefore be subject or liable to any Indictnent or Prosecution for Conspiracy, or to any other Criminal Information or Punishment whatever, under the Common or the Statute Law." (Italics added.) The Act legalized other activities of unions and in doing so was deemed by Parhiament to go too far, and the latter provisions were repealed in the following year. 6 Geo. IV (1825) c. 129. The Act of 1825 contained a provision (\$ 4) similar to the one above referred to in the Act of 1824, that laborers entering into agreements to fix wages "shall not be liable to any Prosecution or Penalty for so doing; any Law or Statute to the contrary notwithstanding." The Act also contained a provision ( $\$ 5$ ) legalizing in like manner agreements between employers, verbal or written "for the Purpose of fixing the Rate of Wages or Prices, which the Parties entering into such Agreement, or any of then, shall pay to his or their Journeymen, Workmen or Servants, for their Work," and that persons entering into any such agreenient "shall not be hable to any Prosecution or Penalty for so doing, any Law or Statute to the contrary notwithstanding." Incidentally, it should be noted that the very fact that Parliainent found it necessary in these statutes to forbid common law prosecutions of 
But apart from a statute in $1825^{113}$ which repealed the statute of 2 \& 3 Edward VI, and legalized agreements between employers fix-

conspiracies to fix wages is in itself additional strong evidence in support of the view that the common law condemned such conspiracies.

The effect of the above quoted provisions of the statutes of 1824 and 1825 was problematical. In terms they said only that parties to such agreements would not be liable to any "Prosecution or Penalty" for entering into them. This clearly prevented criminal prosecutions but did not provide that such agreements were lawful to such extent as to be enforceable by civil action. A liberal construction of the word "Penalty" might well have been made, to make such agreements wholly lawful and enforceable, particularly in view of the fact that the acts of 1824 and 1825 repealed in toto the many old statutes referred to above, condemning wage-fixing agreements. As pointed out above, those statutes in nearly every case did two things: (1) they made such agreements illegal and void; and (2) they attached criminal penalties in addition thereto. If Parliament had intended to provide only that wage-fixing agreements are no longer criminal but still unlawful so as to be unenforceahle, it seems incomprehensible that it would have repealed these old statutes in toto rather than provide merely that such agreements should no longer subject the parties thereto to criminal prosecution. The first Enghish cases to express an opinion on the question apparently took this view. Regina v. Harris (1842) 1 C. \& M. 661, 662, n. (a) (stating that a mere combination to raise wages "is no more than is recognized as legal by the statute $6 \mathrm{GEO}$. IV; by wbich statute also exactly the same right of combination, to the same extent, and no further, is given to the masters when net together, if they are of opinion the rate of wages is too high."); Regina v. Selsby, cited in (1851) 2 Den. 384, n. (a) ; Regina v. Rowlands (1851) 2 Den. 364, 389, n. (a), (1851) 17 Q. B. 671, 688, n. (b). These dicta were overthrown, however, in Hilton v. Eckersley, supra note 13, which involved a comhmation of masters turning over management to a majority of them for one year. The court stated that combinations of either masters or laborers, to lower or raise wages were illegal as in restraint of trade, notwithstanding the provisions of the Act of 1825, which was construed as removing criminality from such combinations but not illegahty in the sense of allowing enforcement in a civil action, thus making labor unions "something bike betting and gambling." LaNDIs, op. cit. supra note 56, at 20. The rule of Hilton v. Eckersley was applied in Hornhy v. Close (1867) L. R. 2 Q.B. 153 , and a lower court judgment affirmed by an equally divided court of exchequer chamber in Farrer v. Close (1869) L. R. 4 Q. B. 602, to lold labor organizations illegal because of provisions existing in their by-laws requiring support of striking inemhers. It seems not to have been applied to cases involving only wage-fixing agreements, unmixed with other elements. On the contrary, the development in cases involving the fixing of prices, heremafter considered, indicates that wage-fixing agreements would ultimately have been held valid and enforceable at common law. See also Springhead Spinning Co. v. Riley (1868) L. R. 6 Eq. 551, 558, where it was indicated that a combination "to keep up the price of wages" without intimidation or violence was valid. The matter was set at rest by the enactment of the Trade Union Act, 1871, 34 \& 35 VICT., c. 31, §3, providing that "The purposes of any trade union shall not, by reason merely that they are in restraint of trade, be unlawful so as to render void or voidable any agreement or trust." See Hedges and Winterbottom, op. cit. supra note 93, pt. 2, c. 1. Thereafter the case of Collins v. Locke, supra note 15, indicated that such result would have been attained without the statute.

1136 Geo. IV (1825) c. 129. The repeal of the price-fixing provisions of the statute of 2 \& 3 EDw. VI (1548) c. 15, seems clearly to have been accidental and merely incidental to the main desire to repeal the provisions relating to wage-fixing agree- 
ing wages, and a statute in $1844^{114}$ forbidding prosecution of forestalling, engrossing, and regrating as common law crimes, no similar statutory aid was forthcoming in support of agreements fixing or affecting prices, or otherwise restraining competition. The courts were faced with the alternative of either applying the common law rule as previously declared or abandoning it. After a somewhat equivocal start in Cousins v. Smith, ${ }^{115}$ they definitely chose the latter course and by a series of decisions established the rule that price-fixing agreements, and even agreements providing for pooling of profits or the division of territory or markets, were valid if reasonable.

Thus in Hearn v. Griffin, ${ }^{116}$ decided by the Court of King's Bench in 1815, where two competing owners of coaches entered into an agreement to charge the same price to passengers, the agreement was upheld on demurrer in an action to enforce it, over the objection that it was "in restraint of that competition in trade which is so conducive to the interest of the public...." The court stressed two features: that the parties had or would have sufficient outside competition to prevent their exacting exorbitant prices; and that the agreement was

ments, since none of the early price-fixing statutes above referred to were repealed at this time. Section 5 of the act expressly legalized combinations of masters to depress wages. See sitpra note 112 .

1147 \& 8 Vicr. (1844) c. 24, providing that "no Information, Indictment, Suit or Prosecution shall lie either at Common Law or by virtue of any Statute ... for or by reason of any of the said Offences...."

115 Supra note 60, an agreement among a group of wholesale grocers who combined to form a coinmittee to purchase through combination with steamship lines the entire supply of fruits imported into England at low prices and to resell them to wholesalers at prices apparently fixed by the committee. Lord Eldon said that this was neither forestalling, regrating, nor monopolizing but contains the mischief of all three, adding "First, there is a conspiracy against the vendors; next, a conspiracy against the world at large; enabling those persons to buy at any price they may think proper; and then, it is true, they can, if they please, sell at a lower price than a fair competition in the market would produce: but it must also be recollected, that they can sell upon their own terms; and the manner, in which that discretion will probably be exercised, is obvious." Ibid. at 545 . The case clearly does not condemn all price-fixing agreements, but comes close to condemning them as unlawful per se where control of the market exists. In this respect the case is not clear. The criticism of the decision later made by Lord Campbell seems without foundation and also indicates that the prevailing opinion at the time when Lord Campbell wrote, i.e. 1847, was that there was nothing unlawful about a price-fixing agreement, since, as Lord Campbell puts it, the parties can accomplish the same result by a partnership agreement. See 7 CaArpbeld, Lives of THE LORD CHANCELlors (1848) 653-654.

116 (1815) 2 Chitty 407, 408. At least two judges participated in the decision, viz., Ellenborough and Bayley, and perhaps three or four in view of the custom at this time to have three or four judges sit in a case. Judgment was not actually entered in the case because of a settlement reached by the parties. 
a convenient node of arranging two concerns which might ruin each other.

Shortly thereafter the Court of Exchequer, in 1829, in the case of Wickens v. Evans, ${ }^{11 \tau}$ upheld an agreement between three competing box and trunk manufacturers dividing England and Wales into three parts, one of which was assigned to each of the contracting parties for life, the parties agreeing not to compete with one another in the assigned territories. In addition, the agreement provided that the parties would not purchase any chests in Oxford at a higher price than $6 \mathrm{~d}$. or $8 \mathrm{~d}$. each. In an action to recover damages for breach of the agreement a deinurrer, interposed on the ground that the agreement was void as being in restraint of trade, was overruled. Three separate opinions were delivered by the judges who sat in the case. All agreed that the validity of the agreeinent was to be determined by the rule of Mitchel $v$. Reynolds, ${ }^{118}$ i.e., whether the restraint was general and, therefore, void, or partial and, therefore, valid if reasonable in the interests of the parties and the public. Here, reasoned the judges, the restraint was partial, since not extending to all England, and was reasonable in the interest of the parties as eliminating an expensive and ruinous competition. It was reasonable with respect to the public, also, said the court, because it did not create anything like a monopoly, since other box and trunk manufacturers could come into any of the assigned territories and compete with the parties to the agreement. This decision obviously.goes much farther than Hearn v. Griffin, for the agreement eliminated not merely price competition but all other competition as well in the assigned territories. It also provided for the direct fixing of maximum purchase prices. It obviously refutes conclusively the theory of Judge Taft in the Addyston Pipe case that agreements restraining competition which were not ancillary to some other lawful contract were unlawful per se.

Additional evidence in refutation of that theory is found in Shrewsbury \& Birmingham Railway Co. v. London \& Northwestern Railway Co., ${ }^{119}$ where an agreement between two previously compet-

117 Supra note 15.

118 (1711) 1 P. Wms. 181, which announced the rule that if a covenant restraining trade were general, applying to all England, it would be held void, but if partial only it would be upheld, if reasonable in the interests of the parties and not harmful to the public interest. The case upheld a covenant by the vendor incident to the sale of a bakeshop not to exercise the trade of baker within the parish for five years.

119 (1851) 17 Q. B. 652. 
ing railroads not to compete against each other for traffic on a certain part of their lines and to divide profits on that part was upheld. Chief Justice Canpbell said:

'The defendants' counsel contended that it is injurious to the public by giving in effect a inonopoly to the plaintiffs, and thereby depriving the public of the benefit that might be derived froin competition. If this were so, and the parties proposed by their agreement to endeavor to prevent competition generally, there might be weight in the objection; but the effect of the agreement is only that the one Company shall not compete or interfere with the other upon the particular line mentioned in the agreement. This is no more illegal than it would be for two persons engaged in trade to agree that one shall not exercise his trade nor compete with the other within a particular district." 120

To the argument that the agreement would injure shareholders because of the provision for dividing of profits, the court answered that: "... this arrangement may be greatly for the benefit of. the shareholders; and without such coöperation of the two Companies perhaps no profit would be made."121

The next case, Hilton v. Eckersley, ${ }^{122}$ decided by the Court of Exchequer Chamber in 1855, held illegal and unenforceable as in restraint of trade a bond given pursuant to an agreement by all the owners of cotton mills in and around Hindley, in the county of Lancaster, to give similar bonds, the bonds being conditioned on the obligor-employer carrying on his works "in regard to the amount of wages to be paid to persons employed therein, and the times or periods of the engagement of work-people, and the hours of work, and the suspending of work, and the general discipline and management of their said works and establishments" for a period of twelve inonths, in conformity with the resolution of a majority of obligors present at a meeting convened in the manner provided in the bond. While the court announced a broad principle that agreements restricting in any respect the right of any trader to carry on his trade as he saw fit were illegal and unenforceable, although not necessarily criminal, it nevertheless was at pains to point out particular features of the agreement which made it unreasonable. Thus it placed emphasis on the turning over by the parties of the entire management and control of the com-

120 Ibid. at 668 .

121 Ibid, at 669.

122 Supra note 13, at 49. (Italics added.) 
peting enterprises for a twelve-month period with full power to close any or all of the works if they saw fit. If the court had stopped here, the case would obviously not bear upon the question of the validity of a mere wage-fixing agreement unmixed with other elements. It did not, however, but instead concluded its opinion with a gratuitous observation that if agreements of the character here involved were enforceable by masters, then agreements to like effect between laborers must be equally enforceable, "and so we shall be giving a legal effect to combinations of workmen for the purpose of raising wages, and make their strikes capable of being enforced at law," 123 and added that the legislature was content to make such strikes not punishable and did not contemplate allowing their enforcement by civil action. The latter statement was a clear enough indication that the principle of the case was not limited to condemnation of the drastic type of agreement actually before the court, but condemned as unlawful, but not criminal, all agreements for the fixing of wages, whether by masters or laborers. It also amounted to a construction of the statute of 6 George IV as merely removing the taint of criminality from agreements of laborers or employers for the fixing of wages-not as also removing the taint of illegality. As a matter of statutory construction this conclusion seems unwarranted. ${ }^{124}$ In any event, however, the language immediately raised the question whether all agreements fixing prices were not now to be regarded as unlawful per se although not criminal, for it is difficult to distinguish on principle between an agreement by masters fixing wages and one fixing prices. It should be observed, however, that neither counsel nor any of the judges of either the Court of Queen's Bench or Exchequer Chamber referred to the previous cases of Hearn v. Griffin, Wickens v. Evans, or the Shrewsbury case, so that apparently it was thought that they were not involved. This could be the case only if it be assumed that counsel and the courts had the facts of the Hilton case in mind and believed the restraint of a more serious nature than that presented in the previous cases. It is difficult to believe that the court intended to overrule these cases sub silentio. But if it be conceded that such actually was the intention of the court, there can be no doubt that this position, if in fact ever taken, was quickly abandoned by the English courts and the rule of the previous cases restored.

123 Ibid. at 76.

124 See supra note 112. 
Thus in Hare v. London \& North-Western Ry. Co., ${ }^{125}$ decided six years later, an agreement between competing railroads for the pooling of profits was upheld even though it did not appear that the parties had any outside competition with which to contend. The sole basis for upholding the agreement seems to have been that it was desirable in the interest of preventing a ruinous competition, the court saying:

"It is a mistaken notion, that the public is benefitted by pitting two railway companies against each other till one is ruined, the result being, at last, to raise the fares to the highest possible standard. The Legislature protected the public in a different way, by a provision limiting the maximum of tolls to be taken, and, with respect to fares, it guarded against excessive profits by an enactment in the $7 \& 8$ Vict. c. 85 (a) [sections 1, 2], that, in the event of the profits reaching 10 per cent, the Treasury may revise the scale of fares, and that the Board of Trade may, under certain conditions, purchase the line." 126

The agreement here sustained obviously went much farther than those involved in Hearn v. Griffin and Wickens v. Evans, in that here the parties to the agreement had no outside competition, either present or prospective-in short they controlled the market. Notwithstanding, the agreement was upheld, as was an agreement of exactly the same character in the Shrezesbury case, although in the latter case no point was made as it was made in the Hare case that Parliament had legislated to prevent the exaction of exorbitant rates by railroads.

In 1871 the Court of Chancery of Ontario handed down a decision which has frequently been cited in American cases decided before 1890 and, therefore, may be presumed to have come to the attention of Congress in or before 1890. The case is Ontario Salt Co. v. Merchants Salt Co. ${ }^{127}$ which upheld and enforced in a civil action an agreement between competing salt manufacturers establishing a common selling agency with authority to fix selling prices for the group. The parties did not control the market but were faced with extensive and effective outside competition, and the court relied upon this feature in upholding the agreement. The court observed that the common law had changed since the decision in King v. Waddington, and referred to Hearn v. Grifin and Wickens v. Evans as supporting this conclusion. Hilton v. Eckersley was distinguished on the ground

125 (1861) 2 John. \& H. 80.

$120 \mathrm{lbid}$. at 103. Cf. Midland Ry. v. London \& North Western Ry. (1866) L. R. 2 Eq. $524,531$.

127 (1871) 18 Grant Ch. 540. 
that there "each millowner completely surrendered his right of carrying on trade without restraint to the majority of the associates, who could at any moment they thought fit close the mills altogether."128

Collins v. Locke, ${ }^{129}$ decided by the Privy Council in 1879, upheld an agreement among stevedores in the Port of Melbourne, Australia, insofar as it divided the stevedoring business of the port among them, specific customers being assigned to various parties to the agreement. The court relied on Mitchel v. Reynolds, once more applying the rule of that case to a non-ancillary contract. Clearly this agreement resulted in the elimination of price competition and all other competition between the parties thereto, and yet the agreement was upheld. The case cannot be regarded as consistent with the broader implications of Hilton v. Eckersley.

The last case on this subject to be decided by the English courts prior to the enactment of the Sherman Act was Mogul Steamship Co. v. McGregor, ${ }^{130}$ decided by the Court of Appeal in 1889, and which was still pending on appeal to the House of Lords at the time of the passage of the Sherman Act. The case involved a combination of shipowners engaged in the China trade, who in order to secure that trade exclusively for themselves, agreed, among other things, to offer a rebate of five per cent to all shippers who would deal exclusively with members of the association, in order to drive outside competitors out of business. Plaintiff, who was such an outside competitor,

128 Ibid. at 545. With respect to control of the market, the court said: "It is out of the question to say that the agreement which is the subject of this bill had for its object the creation of a monopoly, inasmuch as it appears from the bill that the plaintiffs and defendants are not the only persons engaged in the production of salt in this province, and therefore the trade in salt produced here by other persons, and in salt imported from abroad, will remain unaffected hy the agreement, except in so far as prices may possibly be influenced by it." Ibid. at 542 . ". . . it also appears that salt, other than the produce of the wells of the plaintiffs and defendants, can be, and is supplied to the public." Ibid. at 549.

${ }^{129}$ Supra note 15 . The agreement also provided that if the customer assigned to a given party refused to deal with such party, then the party obtaining such customer should pay the proflts to the party originally assigned such customer. This clause was also upheld. The court said: "The objects which this agreement has in view are to parcel out the stevedoring business of the port amongst the parties to it, and so to prevent competition, at least among themselves, and also, it may be, to keep up the price to be paid for the work. Their Lordships are not prepared to say that an agreement, having these objects, is invalid if carried into effect by proper means, that is, by provisions reasonably necessary for the purpose, though the effect of them might be to create a partial restraint upon the power of the parties to exercise their trade." Ibid. at 685 .

130 (1889) 23 Q.B.D. 598, af'd, [1892] A.C. 25. 
sued to recover damages for injury caused to him by the combination. Lord Coleridge, in the trial court, ruled that the agreement did not restrain trade and held for the defendants. The Court of Appeal affirmed this ruling by a divided court. Lord Esher, dissenting, thought the agreement not only unlawful but criminal at common law, relying on the eighteenth century authorities referred to above, and the broad general language of Hilton v. Eckersley. Lord Justices Bowen and Fry were of a different view, and after indicating that the agreement was probably not in restraint of trade-that it was impossible actually to restrain trade by any such device in a free trade country because of the strong outside competition-held that even if it be conceded that the agreement were void as in restraint of trade, the only result was that it could not be enforced as between the parties thereto, not that damages could be recovered by other persons injured thereby. There is nothing to be found in the opinions of either Bowen or Fry which gives any support to the view that all pricefixing agreements are unlawful in restraint of trade at common law. ${ }^{131}$ Hearn v. Griffin, Wickens v. Evans, and other nineteenth century cases announcing a different rule were not overruled. On the contrary, Fry referred to and quoted from Wickens v. Evans with approval. All that can be said is that the court conceded, for purposes of argument only, that the particular agreement before the court was one in unlawful restraint of trade.

The result of the foregoing review is to show-conclusively, it would seem to the writer-that at the time the Sherman Act was adopted the English courts had come around to the view that agreements directly fixing prices, ${ }^{132}$ and even non-ancillary agreements eliminating price and all other competition between the parties thereto, which necessarily restrain trade more, were not unlawful per se but would be upheld if reasonable. There is no indication in the cases that at this time there was even a presumption of illegality against either type of agreement. Such agreements were regarded as reason-

131 In United States v. Trans-Missouri Freight Ass'n, supra note 11, at 334, and Standard Oil Co. v. United States, supra note 6, at 56, the Mogul case is regarded as holding that any agreement to fix prices will be upheld if reasonable.

132 Hearn v. Griffin, supra note 116 (directly fixing specific selling prices); Wickens v. Evans, supra not 15 (fixing maximum purchase prices); Ontario Salt Co. v. Merchants Salt Co., supra note 127 (setting up agency with power to fix selling prices), all upholding agreements because reasonable. Cousins v. Smith, supra note 60 (condemning setting up of agency to fix selling prices after supply cornered); Mogul S. S. Co. v. McGregor, supra note 130 (condemning as unreasonable agreement to depress prices in order to drive competitors out of business.) 
able if made for the purpose of eliminating ruinous competition where the parties did not control the market. ${ }^{133}$ There was no holding or intimation, however, that control of the market necessarily made for invalidity. On the contrary, in at least two cases such control apparently existed and yet the agreements involved were upheld; ${ }^{134}$ in one for the reason that Parliament had safeguarded the public from extortionate rates by legislation preventing such rates. ${ }^{135}$ Where the agreement involved the turning over of the entire management of the competing enterprises to the control of a majority of such enterprises for a long period of time, it was deemed unreasonable and void. ${ }^{130}$ In like manner, where a price-fixing combine was formed for the express purpose of cutting prices so low as to drive competitors out of business, the agreement would be deemed unreasonable and void under the concession made in the Mogul case. Such was the state of the common law authorities in England at the time the Sherman Act was enacted. It can hardly be said to support the analysis of Judge Taft in the Addyston Pipe case.

\section{American Authorities}

Turming to the situation in this country, we find that contrary to general belief the state of the law here prior to the enactment of the Sherman Act was not greatly different from that which we have just found to exist in England. Many cases came before the courts, some of which involved agreements directly fixing prices or wages (the American courts, like the English, treated price-fixing and wage-fixing agreements as being referable to the same principle ${ }^{137}$ ). Others

133 Hearn v. Griffin, supra note 116; Wickens v. Evans, supra note 15.

134 Shrewsbury \& Birminghain Ry. v. London \& Northwestern Ry., supra note 119; Hare v. London \& North-Western Ry., supra note 125. It is not unlikely that control of the market existed in Colkins v. Locke, supra note 15, although the matter is not clear. Cousins v. Smith, supra note 60, came close to holding that an agreement setting up an agency with authority to fix prices was unlawful per se if control of the market existed. See supra note 115 .

135 Hare v. London \& North-Western Ry. supra note 125.

136 Hilton v. Eckersley, supra note 13.

137 In the following cases involving price-fixing agreements, cases involving wagefixing agreements were cited as applicable: Sayre v. Louisville Union Benevolent Ass'n (1863) 62 Ky. 143, 145, (1887) 85 Am. Dec. 613; Skrainka v. Scharringhausen (1880) 8 Mo. App. 522, 527; Hooker v. Vandewater (N. Y. 1847) 4 Denio 349, 353, (1883) 47 Am. Dec. 258; McBirney \& Johnston White Lead Co. v. Consolidated Lead Co. (Cincinnati Super. Ct. 1883) 8 Ohio Dec. 762, 763; Hoffman v. Brooks (Cincinnati Super. Ct. 1884) 6 Ohio Dec. 1215, 1218; Morris Run Coal Co. v. Barclay Coal Co. (1871) $68 \mathrm{~Pa} .173,186,187,188$.

Conversely, in the following cases involving wage-fixing agreements, cases involv- 
involved agreements not only directly fixing prices or wages but other elements as well, such other elements usually consisting of a further agreement to pool profits or divide territory or markets. Still others involved only such "other elements" and not direct price-fixing. Finally, some involved agreements not directly fixing prices or eliminating price competition but merely "affecting" prices.

It has been customary for both courts and writers to treat all of the above types of cases as parallel, and to cite cases condemning one type of agreement as conclusive on the other. ${ }^{138}$ Even Mr. Justice Stone, in the Trenton Potteries case, ${ }^{139}$ indulged in this practice. It is plain, however, that the cases are not parallel and should not be so treated. To illustrate, cases involving the pooling of profits are frequently cited as controlling in a case involving only the direct fixing of prices, and are accepted by the court as such. It is clear, however, that a pooling agreement involves a nuch more serious restraint on trade and competition than a mere direct price-fixing agreement. A pooling agreement restrains trade to the same extent as does such a price-fixmg agreement, since all incentive for price competition is thereby removed. But it goes much farther, however, for it also removes the incentive for any competition whatever, whether of price or otherwise. ${ }^{140}$ Accordingly, there would seem to be a strong basis for regarding a pooling agreement inuch more unfavorably under the antitrust laws than a price-fixing agreement. Indeed this writer could not quarrel with a rule which held pooling agreements unlawful per se

ing price-fixing agreements were cited as applicable: Lee v. Louisville Pilot Benevolent \& Relief Ass'n (1867) $65 \mathrm{Ky} .254,256$; People v. Fisher, supra note 93, at 16, $28 \mathrm{Am}$. Dec. at 505 (citing King v. Norris, supra note 94, but not by name); Commonwealth v. Carlisle ( $\mathrm{Pa} .1821$ ) Bright. N. P. 36, 40 (referring to combination to fix price of bread as parallel).

138 As illustrative of this practice, see Watkins, loc. cit. supra note 20; Note (1932)

32 Cor. L. REv. 291, 295, n. 18.

139 Supra note 8 , at 400 , n. 1, where Mr. Justice Stone referred to several cases as supporting his view even though he recognized that "In many of these cases pricefixing was accompanied by other factors contributing to the illegality," apparently implying that such "other factors" made no difference.

140 See Anderson v. Jett, supra note 14, at $379,-12 \mathrm{~S}$. W. at 671 , where the court in making this very point, said: "This combination [pooling agreement] was more than that of a combination not to take freight or passengers at less than certain prices. In such case, the combiners have to furnish adequate means of transportation and efficient and polite officers, and confine themselves as nearly as possible to the sum agreed upon, in order to secure the trade, or a reasonable portion of it; but here, by reason of the agreement, there is no incentive to competition." See also Judge Sanborn's remarks on this point in United States v. Trans-Missouri Freight Ass'n, supra note 14, at 65, indicating that the pooling agreements are unlawful per se. 
under the antitrust laws, but can see no sound reason for striking down all direct price-fixing agreements as unlawful per se.

In reviewing the American authorities it has been deemed important to take note of these differences rather than to ignore them, as has previously been the custom. Such differentiation reveals many significant facts, as will hereafter appear.

\section{(a) Authorities Involving Agreements Directly Fixing Prices and No Other Element}

Examination reveals that during the period prior to the enactment of the Sherman Act the validity of horizontal agreements, combinations, or conspiracies relating solely to the direct fixing of prices or wages came before the courts of this country in ten cases. In seven of these cases agreements were held valid, ${ }^{141}$ while in only three ${ }^{142}$

141 Commonwealth v. Carlisle, supra note 137 (holding conspiracy between shoc manufacturers not to cmploy any journeymen who would not work for reduced wages would be legal if not entered into for purposes of extortion or oppression but merely to resist a combination of journeymen to raise such wages above their real value); Commonwealth v. Moore (Phila. Mayor's Ct. 1827) 4 Comprons and GmMore, op. cit. supra note 92 , at 99 (laborers indicted for conspiracy to raise wages acquitted on instruction that where such a conspiracy not entered into for purposes of cxtortion or oppression it is valid); Case of Hartford Carpet Weavers (Conn. Super. Ct. 1836) cited in Master Stevedore's Ass'n v. Walsh, supra note 92 at 9 (instrncting jury that conspiracy by laborers to raisc wages not indictable); Lec v. Louisville Pilot Benevolent \& Relief Ass'n, supra note 137 (upholding by-law of association of pilots allowing majority of members to fix wages for all); Master Stevedores' Ass'n v. Walsh, supra note 92, (uplrolding by-law of stevedores' union fixing minimum wages); Skrainka v. Scharringhausen, supra note 137 (upholding agreement between 24 operators of stone quarries in city of St. Louis setting up agency to sell for all at fixed prices); Central Shade Roller Co. v. Cusliman (1887) 143 Mass. 353, 9 N. E. 629 (upholding agreement between manufacturers of shade rollers setting up corporate selling agency to sell at prices specified in such agreement).

No substantial objection can be made to the inclusion of the labor cases in the above list. As leretofore pointed out, the price-fizing and wage-fixing cases have been treated as parallel. And as will hereafter appear, Judge Taft relicd very strongly, in fact more strongly than appears on the face of the opinion, on the case of More $v$. Bennett (1892) $140 \mathrm{Ill} .69,29 \mathrm{~N}$. E. 888, a labor casc, in support of his conclusion in the Addyston Pipe case, supra note 27 , at 289.

142 Sayre v. Louisville Union Benevolent Ass'n, supra note 137 (holding unlawful agreement between owners of steamboats forming association and agreeing to abide by rates fixed by such association-the case seems inconsistent with and therefore may be deemed overruled by Lee v. Louisville Pilot Benevolent \& Relief Ass'n, supra note 137); Central Ohio Salt Co. v. Guthrie (1880) 35 Ohio St. 666 (agreement between salt manufacturers forming association and conferring on committee thereof the power to fix selling prices for all, held invalid); McBirncy \& Johnston White Lead Co. v. Consolidated Lead Co., supra note 137 (agreement between manufacturers of white lead forming corporate selling agency with power to fix selling prices beld illegal). It should 
were they held invalid, and one of the latter cases appears to have been overruled. The very fact that such agreements were upheld more often than they were condemned in these cases is itself conclusive evidence that the view that all price-fixing agreements are unlawful per se did not prevail during this period. Closer examination bears this out to an even greater degree, for not one of the three cases holding price-fixing agreements invalid did so on the express ground that all price-fixing agreements are unlawful per se at common law, and only one can be said doubtfully to support that view by inference. ${ }^{143}$

Further examination of the reasoning of these cases reveals several interesting facts. In five of the seven cases upholding agreements it was presumed that prices fixed were not unreasonable or extortionate, indicating that if the prices fixed were unreasonable or extortionate the agreement would be held invalid. ${ }^{144}$ It also indicated, however, that illegality of a price-fixing agreement was not even presumed. In one of the three cases holding agreements invalid, it was pointed out that the agreement authorized the fixing of unreasonable prices, and it was clearly announced that a price-fixing or wage-fixing agreement would be upheld if it provided only for the fixing of reason-

be noted that in Hoffman v. Brooks, supra note 137, reference is inade to a decision of the Indianapolis Superior Court rendered April 25, 1885, condemning an agreement between insurance compamies fixing rates. It should also be observed that in Gulf, Colo. \& S. F. Ry. v. State (1888) 72 Tex. 404, 10 S. W. 81, an agreement between competing railroads, forming a traffic association with power to fix rates was held illegal under a Texas constitutional provision forbidding railroad corporations from controlling parallel or competing lines. The court did not rely on the common law.

143 Central Ohio Salt Co. v. Guthrie, supra note 142, where the court, in condemming a price-fixing agreement, rejected as immaterial the argument that the parties were subject to effective outside competition, i.e., they did not control the market, and also said that the results or the actual effect of the agreement on the public were not material. This seems tantamount to condemning all price-fixing agreements. The "doubt" above referred to is caused by McBirney \& Johnston White Lead Co. v. Consolidated Lead Co., supra note 137, where the court seemed to regard the Guthrie case as one where the parties to the agreement possessed monopoly power, and Hoffman v. Brooks, ibid., where the Guthrie case is not treated by the court as holding that all price-fixing agreements are unlawful per se.

144 Lee v. Louisville Pilot Benevolent \& Rehef Ass'n, supra note 137; Central Shade Roller Co. v. Cushman, supra note 141; Skrainka v. Scharrimghausen, supra note 137 (holding evidence did not show prices had been raised unduly); Commonwealth $\mathrm{v}$. Carlisle, supra note 137 (indicating power to exact and exaction of exorbitant prices was reason for condemning a price-fixing agreement, but refusing to assume agreement involved was necessarily of that character); Commonwealth v. Moore, op. cit. supra note 141 (saine). 
able prices and its purpose was to eliminate "undue" competition. ${ }^{145}$ The cases are not clear on the question of the extent to which control of the market was material. In only one case was an agreement upheld on the ground that the parties thereto did not control the market, ${ }^{146}$ and in only one did the presence of such control clearly influence a decision invalidating an agreement. ${ }^{147}$ In only one case was it held (apparently) that a price-fixing agreement was illegal even when there was no control of the market. ${ }^{148}$ On the other hand, in only one case was an agreement upheld even where control of the market apparently existed. ${ }^{149}$ In two cases upholding agreements the court stressed the fact that the agreement was entered into for the purpose of resisting an illegal combination by others, i.e., that it was purely defensive-as constituting a justification therefor. ${ }^{150}$

Accordingly, it certainly cannot be said that at this time American courts held that agreements directly fixing prices or wages were unlawful per se at common law. On the contrary, it does not even appear that a presumption of illegality was raised against them.

\section{(b) Authorities Involving Agreements Directly Fixing Prices and other Elements Restraining Competition as Well}

The ten cases just discussed constitute, as has been said, the only cases found which deal with agreements relating solely to the direct

145 Sayre v. Louisville Union Benevolent Ass'n, supra note 137, at 147, 85 Am. Dec. at 616 , in which the court indicated that it would uphold a combination among laborers to obtain only reasonable wages and added that the public interest did not forbid carriers "from guarding themselves against undue competition, reducing freights below the standard of fair competition" and indicated that it would not condemn an agreement between carriers not to carry goods for less than a certain reasonable price. The vice here, said the court, was that the agreement did not confine the parties to reasonable prices but allowed tbe association to fix any price it saw fit, whether reasonable or not. It is difficult to discover any difference in this respect between this and the Lee case, supra note 137, and the latter may therefore be regarded as overruling the Sayre casc. In each power was conferred on an agency to fix prices for all, and the Lee case presumed this meant reasonable prices, while the Sayre case held it meant any price the association saw fit, whether reasonable or otherwise.

146. Skrainka v. Scharringbausen, supra note 137.

147 McBirney \& Johnston White Lead Co. v. Consolidated Lead Co., supra note 137.

148 Central Ohio Salt Co. v. Guthrie, supra note 142.

149 Central Shade Roller Co. v. Cushman, supra note 141, at 364,9 N. E. at 631. This case intimates, but it only intimates, tbat the rule declared in the opimion would not apply to "an article of prime necessity, nor to a staple of commerce, nor to merchandise to be bought and sold in the market." Ibid. What principle does apply in such cases the court does not state.

150 Commonwealth v. Carlisle, supra note 137; Commonwealth v. Moore, op. cit. supra note 141 . 
fixing of prices, unmixed with other elements. But as noted above, there were many other cases decided during this period which involved agreements, combinations, and conspiracies which, while directly fixing prices, or providing therefor, went much further and involved other elements restraining trade and competition. These authorities will now be considered.

(i) Agreements involving direct price-fixing and also pooling of profits. Seven cases involved agreements providing not merely for the fixing of prices but for the division or pooling of profits as well. The agreements were held invalid in six of these cases ${ }^{151}$ and upheld in only one. ${ }^{152}$ The fact that such agreements were held unlawful in all but one of these cases makes a much better case for the view that this more drastic type of agreement was unlawful per se. But while inuch better, it is still a very weak one for it takes no account of the reasoning upon which these decisions were based. In not one of the six cases condemning such agreements did the court hold or say that even this type of agreement was unlawful per se. Furthermore, three of the cases invalidating such agreements were rested exclusively and one partially on special statutes and not the common law. ${ }^{153}$ In two

151 Gibbs v. Baltimore Gas Co. (1889) 130 U. S. 396 (holding illegal an agreement between competing gas companies in Baltimore fixing rates and providing for the pooling of profits); Craft v. McConoughy (1875) 79 Ill. 346, (1878) 22 Am. Rep. 171 (holding illegal an agreement among all the grain dealers of Rochelle, mlinois [five], by which prices, both for the purchase and sale of grain and for the storage thereof were secretly fixed and profits pooled according to agreed percentages, the companies maintaining the outward appearance of being keen competitors); Hooker v. Vandewater, supra note 137 (agreement among five proprietors of boat lines out of 35 operating on Erie \& Oswego Canal fixing rates and dividing net profits held illegal); Stanton v. Allen (N. Y. 1848) 5 Denio 434, (1886) 49 Am. Dec. 282 (agreement between all 35 of such proprietors of boat lines setting up committee to fix rates and providing for division of profits) ; Watson v. Harlem \& N. Y. Nav. Co. (N. Y. 1877) 52 How. Pr. 348 (agreement between competing steamship hines to fix rates, limit number of ships operated, and pool profits held illegal); Hoffman v. Brooks, supra note 137 (holding illegal an agreement among all the tobacco warehousemen in the city of Louisville forming an association for the pooling of profits and authorizing it to fix rates).

152 Dolph v. Troy Laundry Mach. Co. (C. C. N.D.N.Y. 1886) 28 Fed. 553 (upholding agreement between two rival manufacturers of washing inachines for fixing mininum prices, pooling profits, and contemplating termination of manufacture of machines by one). The case amounts to practically a blanket approval of this type of agreement where the article is not a necessary of life and the parties do not control the market. Thus Judge Wallace said: "It is quite legitimate for any trader to obtain the highest price he can for any commodity in which he deals. It is equally legitimate for two rival manufacturers or traders to agree upon a scale of selling prices for their goods, and a division of their profits." Ibid. at 555 .

153 Hooker v. Vandewater, supra note $13 \%$, Watson v. Harlem \& N. Y. Nav. Co., supra note 151, and Gibbs v. Baltimore Gas Co., supra note 151, are based exclusively 


\section{of these cases the courts stressed very strongly the fact that the} parties controlled the market, thereby subjecting the public to the

on special statutes, while Stanton v. Allen, supra note 151 , is based partly on such a statute, and also on the common law. Hooker v. Vandewater was based upon $2 \mathrm{~N}$. Y. REv. STAT. (1829) 691, 692, \& 8, which condemned as criminal any conspiracy "to commit any act injurious ... to trade or commerce." This provision is still on the statute books of New York. See N. Y. PenaI LAW (1909) $\$ 580$ (6). The statutory provision seems to have resulted from the decision of the Senate of New York sitting as the Court of Errors in Lambert v. People (N.Y. 1827) 9 Cow. 578, which reversed a conviction under an indictment charging defendants with a conspiracy to defraud a person of his goods and chattels, apparently (although not clearly) on the ground that to be indictable a conspiracy must be one to do either an unlawful act or a lawful act by unlawful means, and that no indictment lies for a conspiracy to produce a mere private injury, by means which are not criminal and which would not affect the public. That the statute was intended to modify the common law rule seems plain enough from the remarks of the authors of the Revised Statutes, referred to in People v. Fisher, sitpra note 93 , at $17,28 \mathrm{Am}$. Dec. at 505 , and from the language of the court in that case. Thus the court said: "The legislature have given us their definition of conspiracies, and abrogated the common law on the subject. We must therefore see whether this case comes within the statute." Ibid. at 14, $28 \mathrm{Am}$. Dec. at 503. In Stanton v. Allen, supra note 151, and Morris Run Coal Co. v. Barclay Coal Co., supre note 137, the courts held that agreements there involved were contrary to both the common law and this statute, but did not say that the test was the same in either case. In Commonwealth v. Hunt, supria note 90 , at 135 , Chief Justice Shaw took the view that the statute was not simply declaratory of the common law. The same view is taken in Allen, op. cit. supra note 40 , at 540. A similar New Jersey statute was assumed to set up a different criterion than that established by the common law in State v. Donaldson (1867) 32 N. J. L. 151, 154.

A different view is frequently taken, however, and the New York statute regarded as simply declaratory of the common law. Thus in Raymond v. Leavitt (1881) 46 Mich. 447, 452, 9 N. W. 525, 527, Caunpell, J., said that this New York statute "is universally conceded to be a limitation of common-law offenses." The same view is expressed in Jaffe and Tobriner, op. cit. supra note 20, at 1173; Levy, op. cit. supra note 28, at 39; Levy, loc. cit supra, note 28.

Watson v. Harlem \& N.Y. Nav. Co., supra, was based on N. Y. laws 1854, c. 232, which forbade canal or steamship companies fron combining with any other company for any purpose.

Gibbs v. Baltimore Gas Co., supra, while expressing the view that a stricter rule of public policy is applicable to agreements restraining competition between public utilities than those dealing with other types of business, actually limited its holding to a ruling that the agreement was contrary to the provisions of the statute granting the franchise to one of the compamies. Thus the Court said (130 U. S. at 411): "Nor are we called upon to pass upon the validity generally of pooling agreements. Here the contract was directly in the teeth of the statute, which expressly forbade the Equitable Gas-Light Company from entering into it."

In Stanton v. Allen, supra, where the court held the agreement violated the New York conspiracy statute referred to above [2 N. Y. Rev. Stat. (1829) 691, § 8] and was also illegal at common law, the court observed that rates had been actually raised as a result of the agreement. The case also was decided largely on the ground that the canal was a state project and that the result of the arrangement might be to decrease the revenues accrumg to the state in the form of canal tolls. See 5 Denio at 443 . But see 
exercise of arbitrary power, ${ }^{154}$ while in the one case upholding such an agreement lack of control of the market seems to have been the main ground for the decision. ${ }^{155}$ In one case holding such an agreement invalid the court expressly recognized that a price-fixing and pooling agreement would be upheld if its purpose was to end a ruinous competition. ${ }^{156}$ In another, ${ }^{157}$ the court indicated very plainly that the rule declared in Mitchel $v$. Reynolds, and therefore the rule of reason, was applicable to this type of agreement, and that there was no difference between ancillary and non-ancillary agreements in this respect.

(ii) Agreements involving direct fixing of prices and also division of markets. Only one case seems to come within the above category, the often-cited case of Morris Run Coal Co. v. Barclay Coal Co. ${ }^{158}$ which held such agreement to be invalid. This case stressed more strongly than any previous case the fact that the parties to the agreement controlled the market, ${ }^{159}$ and thus had power to exact arbitrary

People v. Sheldon, supra note 9, at 264,34 N. E. at 785 . The court indicated very clearly that a price-fixing agreement with respect to a private business is not unlawful per se. See 5 Denio at 442.

154 Craft v. McConoughy, supra note 151, and Hoffman v. Brooks, supra note 137. Thus im the Craft case the court stressed the fact that the combination "effectually excluded all opposition in the purchase, sale, storage and shipnient of grain in that inarket." Ibid. at 348, 22 Am. Rep. at 173. Later it added that so long as competition existed the public interest was safe but that here the secret combination "destroyed all competition and created a monopoly against which the public interest had no protection." Ibid. at 350, 22 Am. Rep. at 174. (Italics added.) In Hoffnan v. Brooks, the court stressed the fact that the agreement was between all the tobacco warehousemen in the largest tobacco market in the United States, and so distinguished Skrainka v. Scharringhausen, supra note 137.

155 Dolph v. Troy Laundry Mach. Co., supra note 152 . The court reasoned that washing machines were not articles of necessity, that there was no coercion on the public to buy, and that if the price were fixed too high, parties unwilling to pay such prices "could find plenty of mechanics to make such machines," (ibid. at 555) and added that "Certainly, the public have no right to complain, so long as the transaction falls short of a conspiracy between the parties to control prices by creating a inonopoly." Ibid. at 556 .

156 Hoffman v. Brooks, supra note 137, at 1217.

157 Craft v. McConoughy, supra note 151.

15s Supra note 137, holding illegal an agreement between five bituminous coal mining companies appointing a committee to sell their coal and authorizing it to fix selling prices thereof, and also providing for the division of the market between them on the basis of 70 per cent for two of the parties and 30 per cent for the other three.

159 The five parties to the agreement controlled the vast bituminous coal fields of Northern Pennsylvania which supplied New York and large territories westward. It appeared that they were the only companies mining the particular brand of coal mined by them (which was specially adapted to nechanical purposes and the generating of steam) except Cumberland coal, which in order to reach the markets where the coal of 
and extortionate prices from the public. The court did not say or hold, however, that even this type of agreement was unlawful per se. On the contrary it referred to the rule of Mitchel $v$. Reynolds, indicating it was equally applicable to a non-ancillary agreement, ${ }^{180}$ and that this type of agreement might under some circumstances be reasonable.

(iii) Cases involving agreements for fixing of wages by laborers together with other coercive means used. Nine cases decided during the period involved conspiracies by laborers to raise wages accompamied by the use of coercive means to prevent persons from working for employers who refused to pay the higher wages. ${ }^{101}$ In two of these

these parties was sold would have to be shipped by tidewater at a considerable.competitive disadvantage. The court said the important fact was "that these comparies control this immense coalfield; that it is the great source of supply of bituminous coal to the state of New York and large territories westward; that by this contract they control the price of coal in this extensive market, and make it hring sums it would not command if left to the natural laws of trade." $68 \mathrm{~Pa}$. at 184. (Italics added.) The court also added: "They have combined together to govern the supply and the price of coal in all the markets from the Hudson to the Mississippi rivers, and from Pennsylvania to the lakes. This combination has a power in its confederated form which no individual action can confer. The public interest must succumb to it, for it has left no competilion free to correct its baleful influence." Ibid. at 186. (Italies added.) While the court in its statement of facts observed that the coal of these parties was met with competition from Cumberland and anthracite coal in all markets, the language above referred to indicates that such competition was not suhstantial enough to affect the control of the market by the combination. Whether this was due to a limited supply of Cuunberland and anthracite coal or to a price-fixing agreenent hetween the anthracite coal producers and the members of the combination which the agreement provided for, does not appear.

$160 \mathrm{Ibid}$. at 184. The court also approves of Commonwealth v. Carlisle, supra note 137 . See ibid. at 186.

101 The following cases involved conspiracies to raise wages, not to work for any employer who paid less, and to prevent by threats and menaces any other person from working for employers for less: People v. Fisher, supra note 93; New York Cordwainers Case (People v. Melvin) (N. Y. Ct. of Gen. Sess. 1810) 3 Commons and GuMORE, op. cit. supra note 92, at 252; Pittsburg Cordwainers Case (Counmonwealth v. Morrow) (Allegheny Co. Ct. of Quar. Sess. 1815) 4 ibid. at 15; New York Hatters Case (People v. Trequier) (N. Y. Mayor's Ct. 1823) 1 Wheel. Cr. C. 142; Buffalo Tailors Case (Buffalo Ct. of Spec. Sess. 1824) 4 Commons and Grumore, op. cit. sutpra note 92, at 93-95; People v. Faulkner (N. Y. Ct. of Oyer \& Term. 1836) ibid. at 315; Philadelphia Cordwamers Case (Commonwealth v. Pullis) (Phila. Mayor's Ct. 1806) 3 ibid. at 59; Chambersburg Shoemakers (Chambersburg, Pa. Ct. of Quar. Sess. 1829) ibid. at 273. In all of the above cited cases the conspiracy was held illegal. In People v. Cooper, op. cit. supra note 92, at 310, Judge Wilcoxon, after instructing the jury that the case before the court differed from People v. Fisher, and other cases cited above, because in those cases more violence was used than in the present case and compulsion had been used to prevent others from working who were not members of the societies, also told the jury that the case was governed by People v. Fisher and that their verdict should he rendered accordingly. The jury acquitted, however. Three of the above cases, 
-the famous Philadelphia Cordwainers Case ${ }^{162}$ and the decision by the New York Supreme Court in People v. Fisher ${ }^{163}$ - the courts expressed the view that all conspiracies to raise wages or prices were unlawful per se at common law, relying on the pre-nineteenth century English common law cases, referred to above. ${ }^{16 \pm}$ This view was not taken by the other seven cases in this group, however, which stressed the coercive means used by the laborers in order to establish illegality, several of the cases expressly repudiating the view of the Philadelphia Cordwainers Case and People v. Fisher. ${ }^{105}$ It was

People v. Fisher, People v. Faulkner, and People v. Cooper, were prosecutions under the New York conspiracy statute above referred to [N. Y. REv. STAT. (1829) 691, $692, \S 8]$, and not the common law.

162 Loc. cit. supra note 161.

163 Supra note 93.

${ }_{164}$ In the Philadelphia Cordwainers Case, op. cit. supra note 161, at 227, Recorder Levy saw fit to condemn all agreements for raising wages "No matter what their motives were, whether to resist the supposed oppression of their masters, or to insist upon extravagant compensation," relying on King. v. Journeymen-Tailors, supra note 84.

In People v. Fisher, supra note 93, at 15, $28 \mathrm{Am}$. Dec. at 503, the court said: "That the raising of wages and a conspiracy, confederacy or mutual agreement among journeymen for that purpose is a matter of public concern, and in which the public have a deep mterest, there can be no doubt. That it was an indictable offense at common law is established by legal adjudications," citing King. v. Journeymen-Tailors, supra note 84. It also referred to precedents at common law "against journeymen for conspiring to raise their wages and lessen the time of labor, and to compel masters to pay for a whole day's work; against journeymen lamp-lighters, for conspiring to raise wages, and against journeymen curriers for the like offense; 3 Chitty's Cr. Law, 1163, and note 9; against salt-makers, for conspiring to enhance the price of salt" (referring to King v. Norris, supra note 94, without citing it). Ibid. at 16, $28 \mathrm{Am}$. Dec. at 504. But the court also cited common law precedents in which coercive measures in addition to price-fixing were used, and in this connection said that People v. Trequier, loc. cit. supra note 161 (which was such a case) was on all fours with People v. Fisher. See also People v. Wilzig (1886) $4 \mathrm{~N}$. Y. Cr. 403, 413. In 1870 a statute was enacted in New York which exempted "orderly and peaceable assembling or coöperation of persons employed in any profession, trade or handicraft, for the purpose of securing an advance in the rate of wages or compensation or for the maintenance of such rate," from the general conspiracy statute. N. Y. Laws 1870 , c. 19. See People ex rel. Gill v. Smith (1887) $5 \mathrm{~N}$. Y. Cr. 509, 511 et seq. (holding violent strikes still punishable). Obviously this statute did not prevent prosecution of conspiracies at common law. None occurred after this time, however.

Other cases also expressed this view by dictum. Thus in Commonwealth v. Sheriff (Ct. of Quar. Sess. 1881) 15 Phila. 393, the court assumed that a mere agreement or conspiracy to raise wages was illegal at common law, but held that a Pennsylvania statute had changed the rule. In Callan v. Wilson (1888) 127 U. S. 540, 556, the Court said that conspiracy was commonly used "for the unlawful combinations of journeymen to raise their wages.'"

165 In the New York Cordwamers case, op. cit. supra note 161, at 383, the court expressly stated that it "did not mean to say" that an agreement not to work except for certain wages, would amount to this offense "without any unlawful means taken to 
also repudiated in some of the cases referred to above, ${ }^{106}$ and by dicta in other labor cases. ${ }^{167}$ It would seem plain enough, therefore, that the courts of this country regarded it as untenable at an early day. ${ }^{108}$

(iv) Agreements contemplating not only the fixing of prices but of all other terms of sale, as well as whether and when sale shall be made. In two cases horizontal agreements to withhold specified quantities of commodities from the market until a majority of the parties thereto agreed to sell were held invalid. ${ }^{109}$ Obviously these agree-

enforce it." In the Pittsburg Cordwainers Case, op. cit. supra note 161, at 81, the court said "It is not for demanding high prices that these men are endicted, but for employing unlawful means to extort those prices."

166 Case of Hartford Carpet Weavers, supra note 141; Lee v. Louisville Pilot Benevolent Rehief Ass'n, supra note 137; Master Stevedores' Ass'n v, Walsh, supra note 92 ; Commonwealth v. Carlisle, supra note 137; Commonwealth v. Moore, op. cit. supra note 141. In Commonwealth v. Carlisle, Justice Gibson expressly disapproved of the views of Recorder Levy on the subject. He said: "The mere act of combining to change the price of labour is, perhaps, evidence of impropriety of intention, but not conclusive; for if the accused can show that the object was not to give an undue value to labour but to foil their antagonists in an attempt to assign to it, by surreptitious means, a value which it would not otherwise have, they will make out a good defence," (Bright. N. P. at 42) and added, "A combination to resist oppression, not merely supposed but real, would be perfectly innocent. ..." Ibid.

167 In Carew v. Rutherford (1870) 106 Mass. 1, 14, involving conspiracy by laborers to extort money from employer, the court said: "And it is no crime for any number of persons, without an unlawful object in view, to associate themselves together and agree that they will not work for or deal with certain men or classes of men, or work under a certain price. ... " (Italics added.) State v. Stewart (1887) $59 \mathrm{Vt}$ 273, 288, 9 Atl. 559, 568, quoting from Springhead Spinning Co. v. Riley, supra note 112, at 558, stated that "Every inan is at liberty to enter into a combination to keep up the price of wages. ..."' In State v. Glidden (1887) 55 Conn. 46, 75, 8 Atl. 890 896, it was said: "It is no answer to say that the conspiracy was for a lawful purposeto better their own condition, to fix and advance their rate of wages, and further their own material interest. It is certainly true that they had a right to have sucb a purpose. . . " In People ex rel. Gill v. Walsh (1888) 6 N. Y. Cr. 292, 319, aff'd, (1888) 110 N. Y. 663,17 N. E. 871 , the court said: "No doubt exists of the right of the workmen to seek, by all peaceable means, an increase of wages, and all meetings and combinations having that object in view, which are not distinguished by violence or threats, and are lawful therefore, cannot be reasonably condemned or justly interfered with."'

168 This conclusion is strongly supported after careful analysis in Witte, Early American Labor Cases (1926) 35 YALE L. J. 825, 836.

It was recently said that "The early decisions in the United States-the notorious Philadelphia Cordwainer's case and the Fisher case which established the rule that a combination to raise wages was in itself illegal, both expired without a single leading case overruling them." Cohen \& Gerber, Organized Labor or the Sherman Act (1939) 2 Nat. LAw. Gund Q. 103, 116. This view assumes that the cases cited declared the rule set forth, which, as herein shown, and as shown by Witte, is incorrect. It also assumes, contrary to the fact, as is also shown herein, that courts generally agreed with that proposition, which is equally fallacious.

169 India Bagging Ass'n v. B. Kock \& Co. (1859) 14 La. Ann. 168 (agreement relating to India cotton bagging held void at common law, court remarking bagging was 
ments went far beyond mere price-fixing for they gave the combination an absolute veto on sales by members thereof, whether for the reason that the price was too low or for any other reason, arbitrary, capricious, or otherwise.

(v) Agreements involving joint management or trust. Another type of agreement, widely used, and whose wide use was one of the reasons for the passage of the Sherman Act, but which had not come before the courts very frequently prior thereto, was the agreement providing for the turming over of management to a joint committee of representatives of several competitors. Obviously this type of agreement involves much more than direct price-fixing, although it does involve that. Only two cases have been found presenting this feature: (1) the famous case of People v. North River Sugar Refining $C o .{ }^{170}$ where an agreement setting up a voting trust for the stock of all the sugar refineries in the United States was held illegal as in restraint of trade; and (2) State v. Nebraska Distilling Co., ${ }^{171}$ involving a similar arrangement which was not quite as extensive in its area of operation, and which also held the yoting trust agreement illegal. There is nothing in either of these cases to indicate that the courts were condemning this type of agreement as per se unlawful. Condemnation was apparently limited to the specific agreements involved, in the special circumstances therein existing.

(c) Agreements not Involving Direct Fixing of Prices but Which Result in Elimination of Price Competition

A substantial number of cases deal with agreements which did not directly fix prices at all, but which resulted in the elimination of all competition, including price competition, between the parties thereto, and so necessarily restrained trade more than an agreement which stopped at directly fixing prices. Such cases will now be discussed.

(i) Agreements for pooling profits. There were three cases decided during this period which involved only pooling agreements, unmixed with any other element. ${ }^{172}$ In all three cases the agreements were

article of prime necessity); Leonard v. Poole (1889) 114 N. Y. 371, 21 N. E. 707 (agreement to withhold specified quantities of lard from market held to violate New York conspiracy statute above referred to). See supra note 153.

170 Supra note 13 , aff'g (N. Y. 1889) 54 Hun. 354, 7 N. Y. Supp. 406.

171 (1890) 29 Neb. 700,46 N. W. 155.

172 Anderson v. Jett, supra note 14 (holding illegal an agreement between two rival steamboats on the Kentucky River-the only ones operating there between certain points providing for the pooling of the net aggregate profits of each. The court dis- 
held invalid. In none of the three cases, however, did the court lay down as an absolute rule that all pooling agreements are invalid. On the contrary, from the fact that control of the unarket existed in all three cases, it may well be doubted whether the courts meant to condemn any pooling agreements other than those entered into by parties controlling the market, and there is language in the cases supporting this view. Furthermore, another case, not involving a pooling agreement, announced very emphatically that a pooling agreement would be upheld if the rates charged subsequent thereto were reasonable, and the agreement desigued only to eliminate an "unhealthy competition."173

(ii) Non-ancillary contracts ending all competition. Only two cases involving agreements of the above type have been found, Kellogg v. Larkin ${ }^{174}$ and Leslie v. Lorillard Co., ${ }^{175}$ both of which

tinguished the agreement here involved from a mere price-fixing agreement, thereby indicating that it had no intention of hmiting or qualifying anything that was said in Sayre v. Louisville Union Benevolent Ass'n, or Lee v. Louisville Pilot Benevolent \& Relief Ass'n, both supra note 137) ; Texas \& Pac. Ry. v. Southern Pac. Ry. (1889) $41 \mathrm{La}$. Ann. 970, 6 So. 888, (1891) 17 Am. St. Rep. 445 (holding illegal an agreement between two competing railroads to pool earnings on parts of their bines); Emery $v$. Ohio Candle Co. (1890) 47 Ohio St. 320, 24 N. E. 660 (agreement between manufacturers of 95 per cent of candles in United States cast of Utah to divide profits for six years, a meinber being entitled to his share of profits even if he produced no candles at all, held illegal). Because of tbe direct tendency of the agreement in the Emery case, to limit production, owing to its peculiar terminology, this case rests in a special category, different froin the others.

In United States v. Addyston Pipe \& Steel Co., supra note 27, at 289, Judge Taft erroneously regarded the Anderson and Emery cases as price-fixing cases.

In one other case a pooling agreement was held to violate a special state statute. Morrill v. Boston \& Me. R. R. (1875) 55 N. H. 531.

173 Manchester \& Lawrence R. R. v. Concord R. R. (1890) 66 N. H. 100, 20 Atl. 383, upholding an agreement whereby one railroad leased its road to a competitor for 30 years on the reasoning that even a pooling agreement would be valid, since the court approved the case of Hare v. London \& North-Western Ry., supra note 125, which upheld a pooling agreement designed to end a ruinous competition. The court said: "While, without doubt, contracts which have a direct tendency to prevent a healthy conipetition are detrimental to the public and consequently against public policy, it is equally free from doubt that when such contracts prevent an unhealthy competition and yet furnish the public with adequate facilities at fixed and reasonable rates, they are beneficial and in accord with sound principles of public policy. For the lessons of experience, as well as the distinctions of reason, amply demonstrate that the public interest is not subserved by competition which reduces the rate of transportation below the standard of fair compensation..." Ibid. at 127, 20 Atl. at 384.

174 Supra note 16, upholding agreement between millers and warehousemen of wheat in Milwaukee whereby warehousemen agreed not to deal in wheat in Milwaukee for seven months. The court rejected the view that "competition is the life of trade" as "the shibboleth of mere gambling speculation" and that was "hardly entitled to take 
upheld such contracts. Quite clearly these cases go far beyond cases which merely uphold a direct price-fixing agreement, for the agreements there upheld provided in effect not only for the elimination of price competition, but of all other competition as well. No cases prior to 1890 held to the contrary. These cases are of extreme importance, for they show more clearly than any other that the mere fact of an agreement restraining competition not being ancillary to some other lawful contract did not conpel the conclusion or even the presumption that it was illegal. In each case the rule of Mitchel $v$. Reynolds was held applicable to this type of agreement, and the agreement upheld because reasonable. ${ }^{178}$ It should be added that in no case decided prior to the Sherman Act was it held or even intimated that the question of the legality of an agreement restraining competition turned in any way on whether such agreement was or was not ancillary to some other lawful contract. The cases reviewed above show that such was not the law.

The Kellogg case is of importance for the additional reason that it placed great stress on the fact that the parties to the agreement were subject to outside conpetition and did not control the market, indicating that this was a requisite for validity.

\section{(d) Agreements Only "Affecting" Prices}

Cases involving agreements "affecting" prices, but which neither directly fixed prices nor eliminated price competition, strangely enough, were not numerous. In fact no case has been found involvnig only a horizontal agreement limiting production, such as was upheld in England even prior to the nineteenth century. ${ }^{177}$ Some of the cases referred to above condemned agreements having other fea-

rank as an axiom in the jurisprudence of this country," adding, "I believe universal observation will attest that for the last quarter of a century, competition in trade has caused more individual distress, if not more public injury, than the want of competition." Ibid. at 150, $56 \mathrm{Am}$. Dec. at 180.

${ }^{175}$ Supra note 16, uplrolding agreement between competing steamship companies whereby one of them agreed in consideration of paynient of a sum of money not to run its boats in competition with the other on the route from New York to Virginia. The court said: "Whether competition in this particular business would be a public benefaction, or its restraint a source of prejudice, we are unable, of course, to judge. I do not think that competition is mvariably a public benefaction; for it may be carried to sucls a degree as to becoine a general evil." Ibid. at 534, 18 N. E. at 366.

${ }^{176} \mathrm{~K}$ ellogg v. Larkin, suppra note 16 , at 151, $56 \mathrm{Am}$. Dec. at 180 (relying on Mitchel v. Reynolds); Leslie v. Lorillard Co., supra note 16, at 534, 18 N. E. at 366 (relying on Diamond Match Co. v. Roeber (1887) 106 N. Y. 473, 13 N. E. 419, whicls greatly extended rule of Mitchel v. Reynolds).

177 Freemantle v. Conipany of Silk Throwsters, supra note 79. 
tures but which also tended to limit or control production. ${ }^{178}$

In several instances attempts by single individuals to corner the market, ${ }^{178}$ limit production, ${ }^{180}$ or obtain a monopoly by acquisition of the business of competitors ${ }^{181}$ by entering into a series of separate contracts with various individuals looking toward one of those ends were condemned and enforcement of contracts entered into pursuant to such scheme refused. While these schemes were condemned, the cases afford no basis for a conclusion that horizontal agreements affecting prices were unlawful per se.

In one case, Commonwealth v. Tack, ${ }^{182}$ an agreement closely analogous to that presented in the Socony Vacuum case was held not unlawful per se by a Pennsylvania court. The agreement was entered into by defendants to purchase 150,000 barrels of oil on the Antwerp market in order to hold up the price of oil and stimulate it artificially both in Antwerp and the oil markets of the world. It appeared that defendants had previously advised clients to sell oil short and that they had done so. In an indictment for unlawful conspiracy under a Pennsylvania conspiracy statute, which embodied common law principles, the court refused to charge the jury that the agreement or combination was unlawful per se. On the contrary, it said: "It was not per se indictable to raise the price of oil on a given day, neither

178 Watson v. Harlem \& N. Y. Nav. Co., stipra note 151; Emery v. Ohio Candle Co., supra note 172.

179 Raymond v. Leavitt, supra note 153 (refusing to enforce agreement to repay borrowed money where money used by individual to enter into separate purchase to corner wheat supply).

180 Santa Clara Valley Mill \& Lbr. Co. v. HTayes (1888) 76 Cal. 387, 18 Pac. 391, (1899) $9 \mathrm{Am}$. St. Rep. 211 (refusing to enforce agreement to sell quantity of lumber wbich provided vendor not to manufacture any lumber for otber persons during period of agreement, wbere plaintiff had entered into similar contracts with other lumber manufacturers); Clancy v. Onondaga Fine Salt Mfg. Co. (N. Y. 1862) 62 Barb. 395, 407 (refusing to enforce agreement with salt manufacturer in Syracuse to pay more for salt if production of plaintiff were 15,000 bushels or less, defendant having entered into similar separate agreements with all salt producers of Syracuse) ; Arnot v. Pittston \& Elmire Coal Co. (1877) 68 N. Y. 558 (refusing to enforce agreement to buy 2,000 tons of coal, less than the normal production of plaintiff, if latter would agree not to sell coal to any party other than defendant to come north of the state line, where defendant had entered into similar contracts separately with other Pennsylvania coal producers and thus curtailed production and monopolized märket in Western New York).

181 Richardson v. Buhl (1889) 77 Mich. 632, 43 N. W. 1102 (1890) 6 L. R. A. 457, holding unenforceable a contract entered into to forward scheme for purchase by Dianond Match Co. of all competing match companies in the United States. The court indicated that Craft v. McConoughy, supra note 151, Hooker v. Vandewater, supra note 137, Stanton v. Allen, supra note 151, Hoffman v. Brooks, supra note 137, Central Ohio Salt Co., v. Guthrie, supra note 142, Morris Run Coal Co. v. Barclay Coal Co., sutpra note 137 , were all based on control of the market, and that when such control existed agreements such as were involved in those cases are unlawful per se.

182 (Phila. Quar. Sess. 1868) 1 Brewst. 511. 
was it per se an offense to combine honestly to do so." 183 The court charged the jury that "such an agreement is, of itself, not the subject of an indictment." 184 The jury disagreed, but later defendants were acquitted. This case would seem to point to the view that the agreement in the Socony Vacuum case would not have been held unlawful per se at common law prior to 1890 .

In any event, there certainly is not even the slightest vestige of support in the cases before 1890 for any supposed rule that agreements "affecting" prices were unlawful per se. Nor is there any indication that they were regarded as "price-fixing agreements."

\section{(e) Other Cases}

Other cases which do not come within any of the foregoing categories, but which should not go unnoticed, were also decided during this period. In several cases it was held that secret agreements by bidders for property offered for sale at public sales or for public contracts were unlawful as against public policy. ${ }^{185}$ These cases rest upon principles of public policy distinct from the general policy against restraints of trade, and so should not be considered as restraint of trade cases. In another group of cases it was indicated that the rule against restraints of trade was much stricter with respect to public utilities than with respect to other kinds of business and that no restraints, even ancillary to the sale of business or good will, were allowable as to public utilities. ${ }^{186}$ This view does not seem to have been generally recognized. We have seen that it was not accepted in England. ${ }^{187}$

183 Ibid. at 512 .

184 Ibid. at 522 .

185 See Woodruff v. Berry (1882) 40 Ark. 251, and cases therein cited; Atcheson v. Mallon (1870) 43 N. Y. 147. In these cases it is usually stated that such secret arrangements are a constructive fraud on the vendor and the public. Such cases were rarely referred to in restraint of trade cases.

${ }^{186}$ Western Union Tel. Co. v. American Union Tel. Co. (1880) 65 Ga. 160 (contract by railroad company granting telephone company exclusive use of right of way held void on similar reasoning); Chicago Gas Light \& Coke Co. v. People's Gas Light \& Coke Co. (1887) 121 Ill. 530, 13 N. E. 169 (holding rule of Mitchel v. Reynolds not applicable to gas company and covenant not to compete held void); People v. Chicago Gas Trust Co. (1889) 130 Ill. 268, 22 N. E. 798 (holding illegal and dissolving a holding company organized to hold stock of all Chicago gas companies on same principle); West Virginia Trans. Co. v. Olio River Pipe Line Co. (1883) 22 W. Va. 600 (agreement by landowner granting to transportation company exclusive right to lay pipe over lands held void as preventing other companies from competing, saying any restramt of that particular kind of business is unlawful). The view of these cases was apparently approved by way of dictum in Gibbs v. Baltimore Gas Co., supra note 151.

${ }^{187}$ Shrewsbury \& Birmingham Ry. v. London \& N. W. Ry., supra note 119; Hare v. London \& North-Western Ry., supra note 125. 
There were only two cases decided before 1890 which dealt with the question of resale price maintenance. In both such cases agreements providing for the maintenance of resale prices were upheld as against the objection that they were in restraint of trade. ${ }^{188}$

The conclusion is inescapable that the American common law authorities prior to 1890 did not support the proposition that agreements directly fixing prices were unlawful per se. Furthermore, not even non-ancillary agreements eliminating all competition between the parties thereto, including price competition, were deemed unlawful per se. Nor was there anything in the cases to indicate that an agreement "affecting" prices was regarded as unlawful per se, or that such an agreement was regarded as a "price-fixing agreement." Not a single case had amiounced, even by way of dictum, the view declared by Taft to represent the common law, that all restraints on competition which are not ancillary to some other lawful contract are unlawful per se.

On the contrary, the American cases seem to have held, just as the English cases held, that all of the above types of agreement would be deemed unlawful only if found to be unreasonable; that there was no presumption that they were unreasonable; that they were more likely to be held unreasonable where the parties controlled the market, and were more likely to be held reasonable if the parties did not control the market; that they were more likely to be held reasonable if their purpose was to end a ruinous or "unhealthy" competition and were more likely to be upheld if the prices fixed were reasonable.

Such was the state of the common law in this country at the time the Sherman Act was enacted.

Accordingly, if we are to say that Congress intended to embody the rule declared by the common law at the time the Sherman Act was enacted, then it obviously cannot be asserted that the Sherman Act condemns price-fixing agreements as unlawful per se.

That Congress did intend to embody in the Sherman Act the rule thus declared by the cases decided before its enactment is established

188 Fowle v. Park (1889) 131 U.S. 88 (agreement with owner of patent medicine to maintain resale prices of medicines in given territory held not void as in restraint of trade); Clark v. Frank (1885) 17 Mo. App. 602 (enforcing agreement for purchase of thread notwithstanding provision for lower price if defendant maintained resale prices-defendant not having maintained such prices). The Court said in the Fowle v. Park case that the vendors were entitled "to prevent competition between purchasers...." 131 U. S. at 97 . 
by evidence of the most cogent character. In 1928 ex-Representative Washburn of Massachusetts, writing in the Boston Law Review, ${ }^{189}$ set forth an opinion of the late Senator George F. Hoar, who was either the author of the Sherman Act as finally enacted or at least was thoroughly familiar with the views of those who did write it and of other members of Congress. ${ }^{190}$ The opinion was given to members of a combination of manufacturers who had entered into an agreement providing for the fixing of minimum prices and the pooling of profits, who asked his advice on whether the agreement was illegal under the Sherman Act. Mr. Washburn stated that the opinion of Senator Hoar was given on August 22, 1891, thirteen months after passage of the Sherman Act, and that after reviewing many authorities he concluded that the agreement was valid. Senator Hoar's conclusions, as stated by Mr. Washburn, were in part as follows:

" 'Upon the whole, it seems to me very clear that the agreement by each of the persons in the contract above supposed, furnished an adequate consideration for the agreement of all the others. Further, it seems to me that a contract, although in partial restraint of trade, which is reasonable and reasonably limited in point of time, which has for its object merely the saving of the parties from a destructive competition with each other, is not prohibited by the statute above referred to. The question whether this contract is reasonable will be for the court. I think the contract above proposed is reasonable, and would be so held by the courts of the United States....

" This being my opinion, I think the parties to the agreement above supposed would not be likely to be convicted of an offense under the statute of last year." "191

In the next installment of this article it will be shown how and why the courts lost sight of the fact that in 1890 the common law view was as herem indicated, and that Congress intended to incorporate that view into the Sherman Act.

[TO BE CONTINUED]

SCHOOL OF JURISPRUDENCE,

John C. Peppin.

UNIVERSITY OF CALIFORNIA.

189 Washburn, loc. cit. supra note 29.

190 Senator Hoar was a member of the Judiciary Committee of the Senate, which framed the Act, and with the then Chairman of that Committee, the late Senator Edmunds, composed the Senate Committee of conference in matters of disagreement between the Senate and House. Senator Hoar later claimed he wrote the Act. See supra note 29 for statement of rival claims that Senators Sherman, Hoar, and Edmunds wrote the Act.

191 Washburn, loc. civ. supra note 29. 